Prepared in cooperation with the State of Hawai'i Commission on Water Resource Management

\title{
Measurements of Seepage Losses and Gains, East Maui Irrigation Diversion System, Maui, Hawai'i
}

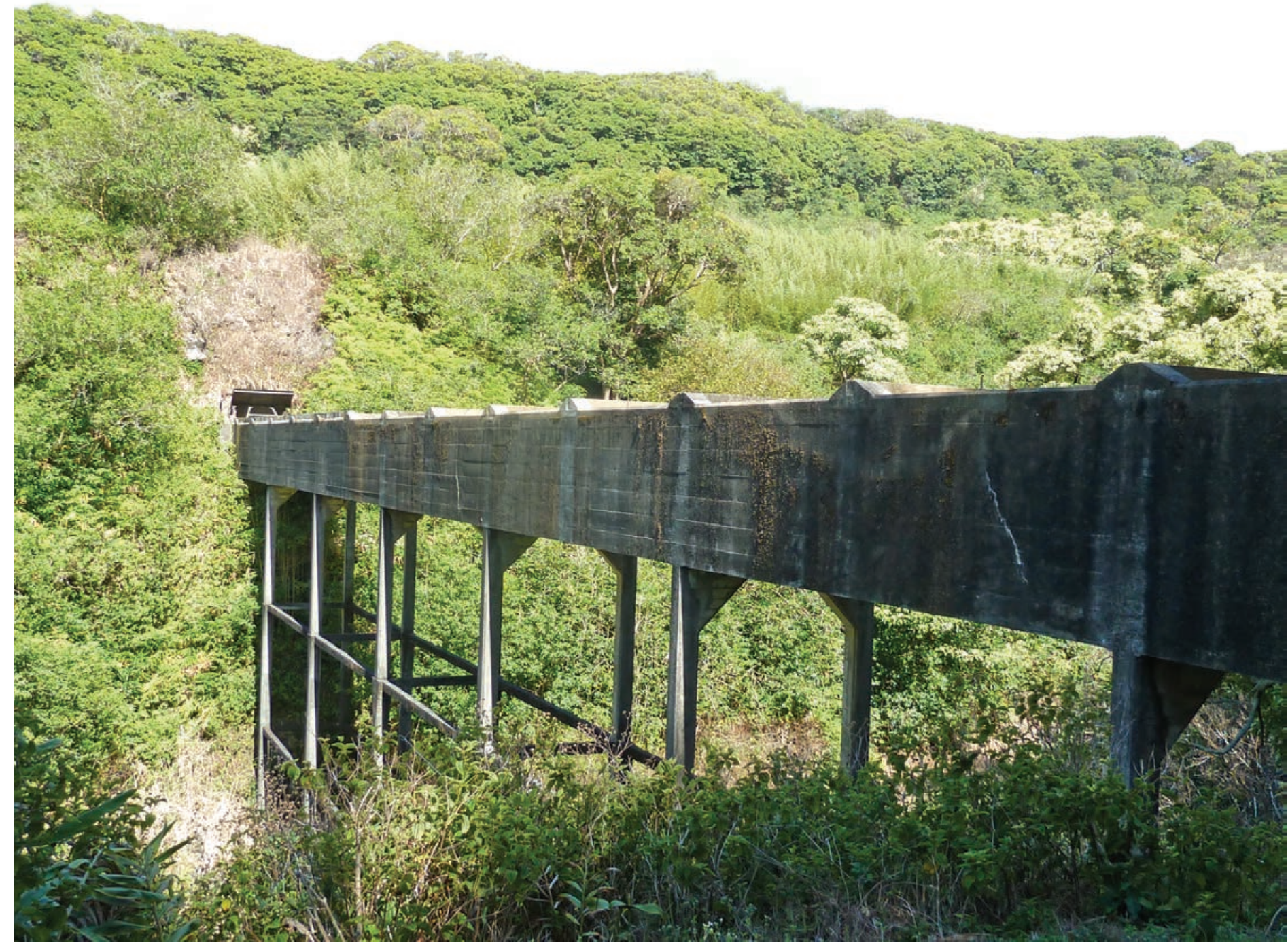

Open-File Report 2012-1115 


\section{Measurements of Seepage Losses and Gains, East Maui Irrigation Diversion System, Maui, Hawai'i}

By Chui Ling Cheng

Prepared in cooperation with the State of Hawai'i Commission on Water Resource Management

Open-File Report 2012-1115 


\title{
U.S. Department of the Interior \\ KEN SALAZAR, Secretary
}

\author{
U.S. Geological Survey \\ Marcia K. McNutt, Director
}

U.S. Geological Survey, Reston, Virginia: 2012

For product and ordering information:

World Wide Web: http://www.usgs.gov/pubprod

Telephone: 1-888-ASK-USGS

This report and any updates to it are available online at: http://pubs.usgs.gov/of/2012/1115/.

For more information on the USGS - the Federal source for science about the Earth, its natural and living resources, natural hazards, and the environment:

World Wide Web: http://www.usgs.gov

Telephone: 1-888-ASK-USGS

Suggested citation:

Cheng, C.L., 2012, Measurements of seepage losses and gains, East Maui Irrigation diversion system, Maui, Hawai‘i: U.S. Geological Survey Open-File Report 2012-1115, 23 p.

Any use of trade, product, or firm names is for descriptive purposes only and does not imply endorsement by the U.S. Government.

Although this report is in the public domain, permission must be secured from the individual copyright owners to reproduce any copyrighted material contained within this report. 


\section{Contents}

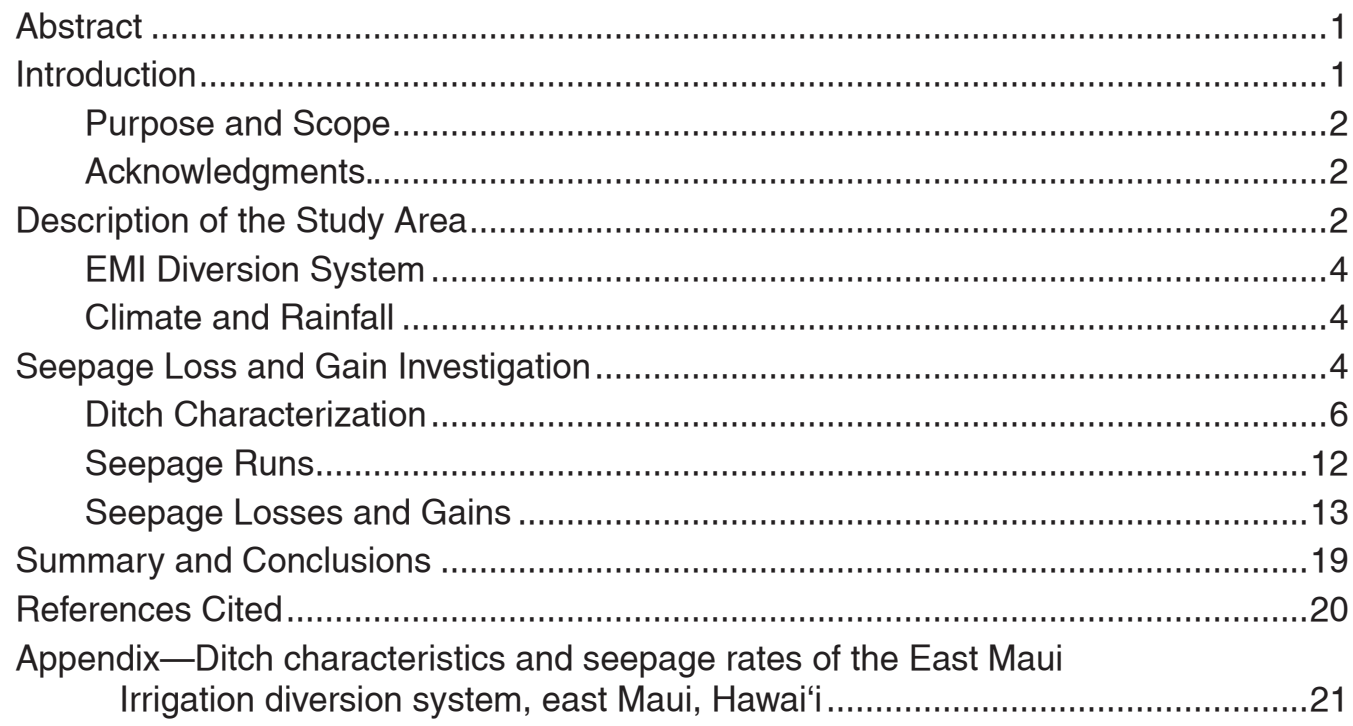

\section{Figures}

1. East Maui Irrigation diversion system, water-license areas, and photographed locations, east Maui, Hawai'i..........................................................................

2. Mean annual rainfall, east Maui, Hawaíi .......................................................... 5

3. Ditch characterization of the East Maui Irrigation diversion system,

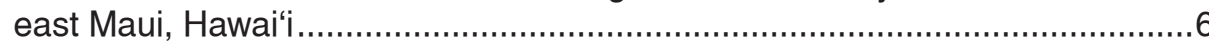

4. Photographs of two flumes that are part of the East Maui Irrigation diversion system, east Maui, Hawai'i .............................................. 8

5. Photographs of two sections of the Ko'olau Ditch, East Maui Irrigation diversion system, east Maui, Hawai'i .............................................9

6. Photographs of two sections of the Spreckels Ditch, East Maui Irrigation diversion system, east Maui, Hawai'i .............................................

7. Photographs of three sections of the New Hāmākua and Kauhikoa Ditches, East Maui Irrigation diversion system, east Maui, Hawai' i ..............................10

8. Photographs of two sections of the Spreckels Ditch at Pāpa'a'ea, East Maui Irrigation diversion system, east Maui, Hawai'i ..............................10

9. Photographs of Manuel Luis, Center, and Lowrie Ditches, East Maui Irrigation diversion system, east Maui, Hawai'i

10. Photographs of two sections of the Ha'ikū Ditch, East Maui Irrigation diversion system, east Maui, Hawai'i 


\section{Tables}

1. Summary of ditch characteristics for the East Maui

Irrigation diversion system, east Maui, Hawai'i

2. Summary of ditch characteristics for seepage-run measurement reaches of the East Maui Irrigation diversion system, east Maui, Hawai'i

3. Seepage-run discharge-measurement stations on the East Maui

Irrigation diversion system, east Maui, Hawai'i

4. Seepage-run measurement reaches with associated discharge measurements, estimated seepage losses and gains, length of measurement reach, and estimated seepage rates of the East Maui Irrigation diversion system, east Maui, Hawai'i.

\section{Conversion Factors}

\begin{tabular}{lcl}
\hline \multicolumn{1}{c}{ Multiply } & By & \multicolumn{1}{c}{ To obtain } \\
\hline inch (in.) & Length & \\
foot $(\mathrm{ft})$ & 25.4 & millimeter $(\mathrm{mm})$ \\
mile $(\mathrm{mi})$ & 0.3048 & meter $(\mathrm{m})$ \\
\hline & 1.609 & kilometer $(\mathrm{km})$ \\
\hline acre & Area & \\
square foot $\left(\mathrm{ft}^{2}\right)$ & 0.004047 & square kilometer $\left(\mathrm{km}^{2}\right)$ \\
square mile $\left(\mathrm{mi}^{2}\right)$ & 0.09290 & square meter $\left(\mathrm{m}^{2}\right)$ \\
\hline \multicolumn{3}{c}{ Volume } \\
\hline gallon $($ gal) & 0.003785 & cubic meter $\left(\mathrm{m}^{3}\right)$ \\
million gallons $(\mathrm{Mgal})$ & 3,785 & cubic meter $\left(\mathrm{m}^{3}\right)$ \\
cubic foot $\left(\mathrm{ft}^{3}\right)$ & 0.02832 & cubic meter $\left(\mathrm{m}^{3}\right)$ \\
\hline & Flow rate & \\
\hline cubic foot per second $\left(\mathrm{ft}^{3} / \mathrm{s}\right)$ & 0.64636 & million gallons per day $(\mathrm{Mgal} / \mathrm{d})$ \\
gallon per day $($ gal/d) & 0.003785 & cubic meter per day $\left(\mathrm{m}^{3} / \mathrm{d}\right)$ \\
million gallons per day $(\mathrm{Mgal} / \mathrm{d})$ & 0.04381 & cubic meter per second $\left(\mathrm{m}^{3} / \mathrm{s}\right)$ \\
inch per year (in/yr) & 25.4 & millimeter per year $(\mathrm{mm} / \mathrm{yr})$ \\
\hline
\end{tabular}

Seepage rate in cubic feet per second per mile of ditch $\left(\mathrm{ft}^{3} / \mathrm{s} / \mathrm{mi}\right)$ may be converted to cubic meter per second per kilometer of ditch $\left(\mathrm{m}^{3} / \mathrm{s} / \mathrm{km}\right)$ as follows: $\mathrm{m}^{3} / \mathrm{s} / \mathrm{km}=0.0176 \times\left(\mathrm{ft}^{3} / \mathrm{s} / \mathrm{mi}\right)$

Temperature in degrees Celsius $\left({ }^{\circ} \mathrm{C}\right)$ may be converted to degrees Fahrenheit $\left({ }^{\circ} \mathrm{F}\right)$ as follows:

${ }^{\circ} \mathrm{F}=\left(1.8 \times{ }^{\circ} \mathrm{C}\right)+32$

Temperature in degrees Fahrenheit $\left({ }^{\circ} \mathrm{F}\right)$ may be converted to degrees Celsius $\left({ }^{\circ} \mathrm{C}\right)$ as follows:

${ }^{\circ} \mathrm{C}=\left({ }^{\circ} \mathrm{F}-32\right) / 1.8$

Vertical coordinate information is referenced relative to local mean sea level.

Horizontal coordinate information is referenced to the North American Datum of 1983 (NAD 83).

Altitude, as used in this report, refers to distance above the vertical datum. 


\title{
Measurements of Seepage Losses and Gains, East Maui Irrigation Diversion System, Maui, Hawai'i
}

\author{
By Chui Ling Cheng
}

\section{Abstract}

The U.S. Geological Survey conducted a field study from March to October 2011 to identify ditch characteristics and quantify seepage losses and gains in the East Maui Irrigation (EMI) diversion system, east Maui, Hawai 'i. The EMI diversion system begins at Makapipi Stream in the east and ends at Māliko Gulch in the west. It consists of four primary ditches known as the Wailoa, New Hāmākua, Lowrie, and Ha 'ikū Ditches. Additional ditches that connect to the four primary ditches include the Ko'olau, Spreckels, Kauhikoa, Spreckels at Pāpa 'a'ea, Manuel Luis, and Center Ditches.

Ditch characteristics for about 63 miles of the EMI diversion system, excluding abandoned ditches and stream conveyances, were identified. About 46 miles ( 73 percent) of the surveyed diversion system are tunnels and 17 miles are open ditches-in which 11 miles are unlined, 3.5 miles are lined, and 2.5 miles are partially lined. The Wailoa, Kauhikoa, and Ha 'ikū Ditches have greater than 96 percent of their total lengths as tunnels, whereas more than half of the Lowrie Ditch and Spreckels Ditch at Pāpa 'a 'ea are open ditches. About 70 percent of the total length of lined open ditches in the EMI diversion system is located along the Ko'olau Ditch, whereas about 67 percent of the total length of unlined open ditches in the diversion system is located along the Lowrie Ditch. Less than 4 percent of the EMI diversion system is partially lined open ditches, and about half of the total partially lined open-ditch length is in the Spreckels Ditch. EMI regularly maintains and repairs the diversion system; therefore, ditch characteristics documented in this report are representative of conditions existing during the period of this study.

Discharge measurements were made along 26 seepagerun measurement reaches that are a total of about 15 miles in length. The seepage-run measurement reaches represent 23 percent of the total length of ditches in the EMI diversion system. Discharge measurements were made along the measurement reaches during periods of stable ditch flow in the months of June, August, and September 2011. The discharge measurements indicate that Ko 'olau Ditch and Spreckels Ditch at Pāpa 'a'ea generally had seepage losses, whereas
Wailoa, Kauhikoa, and New Hāmākua Ditches had seepage gains within the measured reaches. The Manuel Luis, Center, Lowrie, and Ha'ikū Ditches had variable seepage losses and gains within the seepage-run measurement reaches. Openditch measurement reaches generally had seepage losses that ranged from 0.1 cubic feet per second per mile of ditch at the Lowrie Ditch to 3.0 cubic feet per second per mile at the Ko'olau Ditch. Tunnel measurement reaches generally had seepage gains that ranged from 0.1 cubic feet per second per mile at the Manuel Luis Ditch to 5.2 cubic feet per second per mile at the Wailoa Ditch.

\section{Introduction}

Since the late 1800s, the East Maui Irrigation Company (EMI) has been diverting surface water from streams in northeast Maui, Hawai 'i mainly for the irrigation of sugarcane cultivated in the central isthmus of the island. Hawaiian Commercial and Sugar Company (HC\&S) manages the sugarcane plantation, which has been the major sugar producer in the State of Hawai ' $i$ for more than a century. The EMI diversion system collects and transports water emanating from lands between Makapipi Stream to the east and Māliko Gulch to the west, and provides irrigation water for about 30,000 acres of the HC\&S sugarcane plantation. The source of water for the EMI diversion system is primarily surface water from a total watershed area of 87.5 square miles $\left(\mathrm{mi}^{2}\right)$, about two-thirds of which is owned by the State of Hawai' $\mathrm{i}$ (Wilcox, 1996, p. 118) and managed by the State of Hawai 'i Department of Land and Natural Resources (DLNR). In 1938, Alexander and Baldwin, Inc. (A\&B), the parent company of EMI and HC\&S, obtained rights to the water on State of Hawai' $i$ lands pursuant to water leases from four waterlicense areas identified as Nāhiku, Ke'anae, Honomanū, and Huelo, listed from east to west (fig. 1) (Kumu Pono Associates, LLC, 2001). When the water leases expired in 1986, A\&B/EMI received year-to-year revocable permits from the DLNR for diverting water from the streams on State of Hawai'i lands. 
The State Water Code mandates that the State of Hawai 'i Commission on Water Resource Management (CWRM) establish a statewide instream use protection program (State Water Code, Hawai 'i Revised Statutes, chapter 174C, section 71). The principal mechanism that CWRM implements for the purpose of protecting instream uses is establishing instream flow standards that describe flows necessary to protect the public interest in the stream with consideration of existing and potential water developments, including the economic impact of restricting such use (State Water Code, Hawai 'i Revised Statutes, chapter 174C, section 71[1][C]). In September 2008 and May 2010, CWRM established interim instream flow standards for a majority of the streams in northeast Maui that are diverted by the EMI diversion system. CWRM's decision included a comprehensive list of adaptive management strategies, one of which required that "EMI, in coordination with the Commission and USGS [U.S. Geological Survey], shall seek to cooperatively fund and undertake a system efficiency study to accurately determine EMI system losses and/or gains." (State of Hawai 'i Department of Land and Natural Resources, 2010). EMI reported that through a program of regular inspection and maintenance, seepage losses in the diversion system were minimized; however, they were unable to provide measurements or estimates documenting the efficiency of the diversion system (Hawaiian Commercial and Sugar Company, 2010).

The U.S. Geological Survey (USGS), in cooperation with CWRM and in collaboration with EMI, undertook an investigation that aims to provide measurements of seepage losses and gains in the EMI diversion system that are necessary to address CWRM's order to evaluate system efficiency. Moreover, results from this study will provide area water-resource managers with additional hydrologic information to aid in the management of surface-water resources in east Maui.

\section{Purpose and Scope}

The objective of this study is to quantify seepage losses and gains for selected reaches of the EMI diversion system in east Maui, Hawai' $i$. This study provides baseline data that will help determine if there is a need for additional data or a more comprehensive study focused on a particular ditch-construction type(s) or ditch reaches. This study does not address seepage rates of reservoirs that receive water from or are part of the EMI diversion system.

This report documents (1) the locations of tunnel and open-ditch sections of the EMI diversion system, and (2) seepage losses and gains for selected reaches of the diversion system, including tunnel and open-ditch reaches. Seepage losses and gains for each selected reach were computed from same-day discharge measurements of water inflows to and outflows from the reach.

\section{Acknowledgments}

The author gratefully acknowledges the State of Hawai 'i Commission on Water Resource Management and the East Maui Irrigation Company for providing USGS with an opportunity to explore and understand one of the largest and most complex irrigation diversion systems in the State of Hawai'i. The author is especially thankful to EMI for providing access to the entire diversion system and for making certain that maintenance and repair work did not affect parts of the ditch reaches where discharge measurements were being made. EMI personnel Garret Hew, Mark Vaught, Henry Robello, and Kai Andaya were most generous with their time as they accompanied USGS personnel to ensure their safety while working along the access roads and in the ditches.

Thank you to an experienced group of USGS personnel for their dedication and assistance throughout the study. Chiu W. Yeung, Clarence L. Edwards, Richard B. Castro, and Casey J. Rita conducted discharge measurements and helped with all field-related activities. They also shared their diverse knowledge in selecting measurement cross sections, conducting discharge measurements, and using different types of discharge measuring equipment in a variety of conditions. Bobbie L. Arruda and Heather A. Jeppesen assisted with data management. Matt A. Wong and James W. Nelson (USGS Maui Field Office) shared their field equipment. Finally, I appreciate Delwyn S. Oki, Stephen B. Gingerich, Scot K. Izuka, Richard A. Fontaine, and Ronald L. Rickman for their helpful comments and suggestions regarding project design and interpretation of the results.

\section{Description of the Study Area}

The study area (figs. 1 and 2) is located on the northern flank of Haleakalā Volcano, also known as the "East Maui Volcano," which forms the eastern part of the Island of Maui and rises to an altitude of 10,023 feet (ft) at Pu'u 'Ula'ula (Red Hill). Covering an area of about $151 \mathrm{mi}^{2}$, the study area is bounded to the north-northeast by 33 miles of coastline and encompasses 39 drainage basins that the EMI diversion system traverses-from Makapipi in the east to Māliko Gulch in the west. The topography of the northern flanks of the volcano is characterized by the steep walls of many deeply incised valleys, as well as by gently sloping terrain at the intermediate altitudes where dense rain forests exist. The land surface at higher altitudes of the volcano commonly supports grasses and shrubs. 


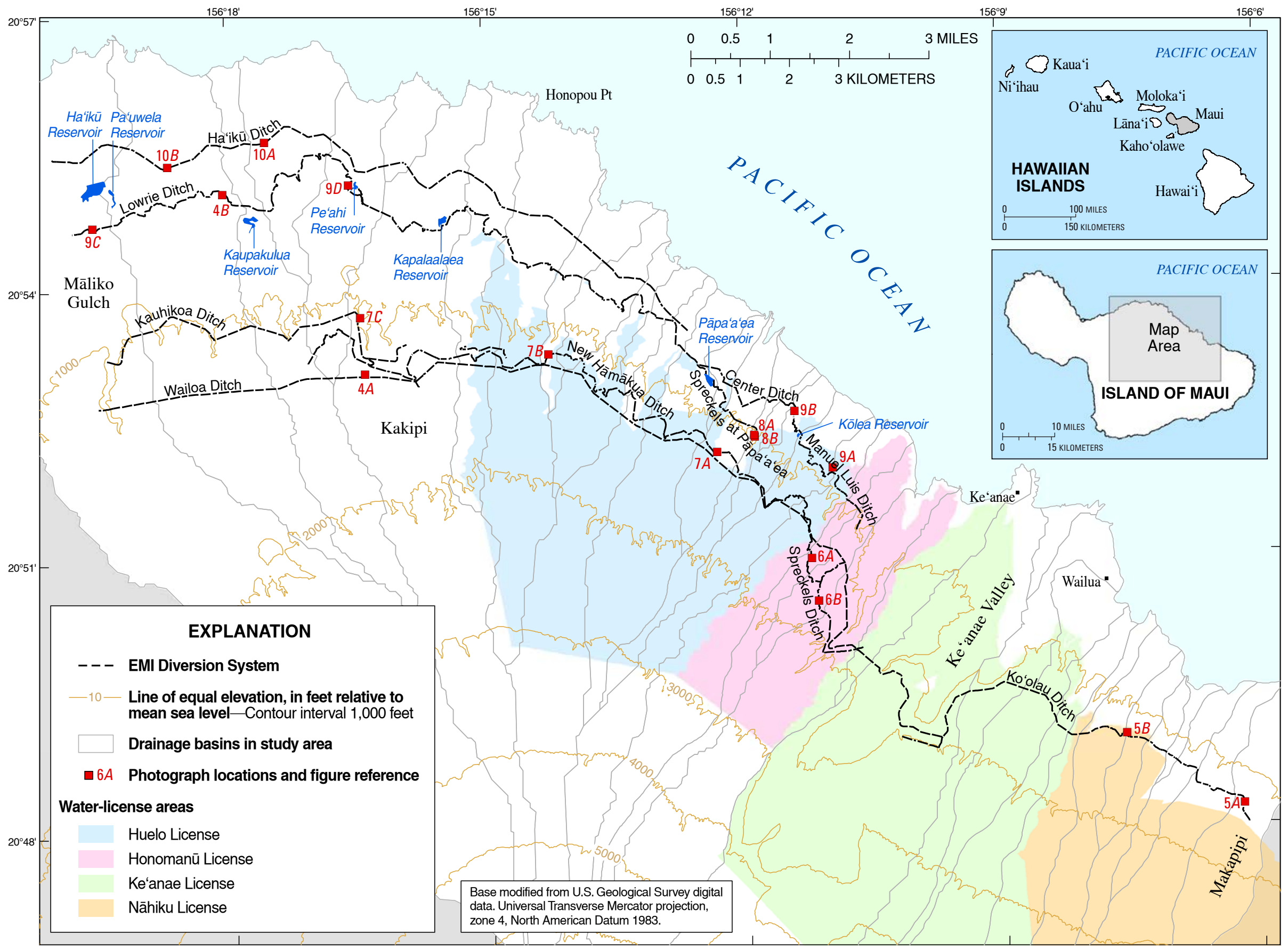

Figure 1. East Maui Irrigation (EMI) diversion system, water-license areas, and photographed locations, east Maui, Hawai'i. 


\section{EMI Diversion System}

The EMI diversion system is a complex water collection and transport system that consists of roughly 388 separate stream-water intakes, 12 inverted siphons, and numerous secondary feeders, dams, intakes, pipes, and flumes (Wilcox, 1996, p. 117-18). The diversion system has four primary levels of ditches: Wailoa, New Hāmākua, Lowrie, and Ha'ikū Ditches, listed from highest to lowest altitude (fig. 1). Additional ditches that connect to the primary ditches include the Ko 'olau, Kauhikoa, Manuel Luis, Center, Spreckels, and Spreckels at Pāpa 'a 'ea Ditches. These ditches are interconnected by short sections that transport water from one ditch to another and natural stream channels that convey diverted water between the ditches. The New Hāmākua and Ha'ikū Ditches function as overflow ditches that capture excess flows from the Wailoa and Lowrie Ditches, respectively.

Ko 'olau Ditch marks the beginning of the EMI diversion system, and it transports water diverted from streams in the eastern half of the study area to Alo Stream (appendix), where the Ko 'olau Ditch is thereafter referred as Wailoa Ditch. Combined, the Ko'olau and Wailoa Ditches make one continuous ditch that is located at the highest altitude of the four primary ditches. The Wailoa/Ko 'olau Ditch traverses the northern flank of the East Maui Volcano along a relatively uniform altitude of about 1,200-1,300 ft. New Hāmākua Ditch is situated immediately below Wailoa Ditch at altitudes of 1,000-1,260 ft. The western end of New Hāmākua Ditch is abandoned; alternatively, flow in the ditch is transferred to Kauhikoa Ditch at the tributaries of Kakipi Gulch (appendix). The lower ditches—-Lowrie and Ha'ikū Ditch—are farther apart in terms of altitude than the upper ditches are. Lowrie Ditch and its connected ditches, Manuel Luis and Center Ditch (appendix), span a larger range of altitudes than the rest of the ditches, ranging from $940 \mathrm{ft}$ near Punalau Stream to 400 ft near Kuiaha Gulch. Ha 'ikū Ditch is located at the lowest altitude of all the ditches in the EMI diversion system and it is situated between the altitudes of 300 and $500 \mathrm{ft}$. All four primary ditches drop in altitude at Māliko Gulch to allow for the transport of ditch water across the gulch to the HC\&S plantation by means of gravity-feed siphons.

The main purpose of the EMI diversion system is to transport surface water, originating from a majority of the drainage basins within the study area, to central Maui for sugarcane cultivation, diversified agriculture, and domestic use through public-water systems. Demand for water from the EMI diversion system is generally the greatest from May to September. During these periods, the diversion system captures most of the water available in the study area streams at the points of diversion. According to Gingerich (1999, p. 15), during the 73-year period 1925-97, the total combined flow for the four primary ditches of the EMI diversion system measured at Honopou Stream averaged about 163 million gallons per day (Mgal/d). During 1924-87, average flows measured at Honopou Stream were $110 \mathrm{Mgal} / \mathrm{d}$ for
Wailoa Ditch, $23 \mathrm{Mgal} / \mathrm{d}$ for New Hāmākua and Lowrie Ditches, and $15 \mathrm{Mgal} / \mathrm{d}$ for Ha 'ikū Ditch.

Parts of the EMI diversion system not assessed in this study include (1) abandoned ditches such as the westernmost section of the New Hāmākua Ditch; (2) ditches that transport water from diversion intakes to the main ditches; and (3) minor diversions that capture runoff water. Although ditch characteristics of Spreckels Ditch were identified, seepage-run discharge measurements were not made there because EMI was repairing the ditch during the study period.

\section{Climate and Rainfall}

Climate in northeast Maui is primarily controlled by trade winds from the east-northeast that create a series of distinct microclimates occurring at different altitudes on the East Maui Volcano. Trade winds are more frequent in the summer months when they are present more than 90 percent of the time (Schroeder, 1993). The study area lies mainly on the windward side of the volcano where the distribution of rainfall is controlled by orographic effects (fig. 2). Orographic rainfall occurs when northeasterly trade winds lift moist air up the windward slopes of the volcano into higher altitudes where the air is cooled, clouds are formed, and rainfall is generated. The study area receives near-daily orographic rainfall resulting in mean annual rainfall of about 140 inches per year (in/yr) near the northeastern coast, rainfall of more than $280 \mathrm{in} / \mathrm{yr}$ on the eastern intermediate slopes, and rainfall of less than $40 \mathrm{in} / \mathrm{yr}$ at the summit of the volcano and in Māliko Gulch (Giambelluca and others, 2011). Mean annual rainfall at the altitude of the Ko 'olau Ditch is the highest of all ditches in the EMI diversion system, averaging about 240 in/yr near Makapipi Stream and decreasing to about $210 \mathrm{in} / \mathrm{yr}$ in Ke 'anae Valley. Mean annual rainfall at the altitudes of the Wailoa and New Hāmākua Ditches ranges from an average of $200 \mathrm{in} / \mathrm{yr}$ east of Kakipi to about $65 \mathrm{in} / \mathrm{yr}$ near Māliko Gulch. Mean annual rainfall at the altitudes of the lower ditches is about $170 \mathrm{in} / \mathrm{yr}$ at the start of the Manuel Luis Ditch, decreasing to about $50 \mathrm{in} / \mathrm{yr}$ at the western end of the Ha'ikū Ditch.

\section{Seepage Loss and Gain Investigation}

Field reconnaissance of the EMI diversion system was done to characterize the ditches, locate diversion structures, and select seepage-run measurement reaches and discharge measurement sites. Accessible parts of the ditches were inspected in the field, and ditch characteristics were documented using visual observations, photographs, and a handheld global positioning system (GPS) unit. To aid the selection of suitable seepage-run measurement reaches, locations of surface-water inflows and outflows were noted along the EMI diversion system. Inflows were typically 


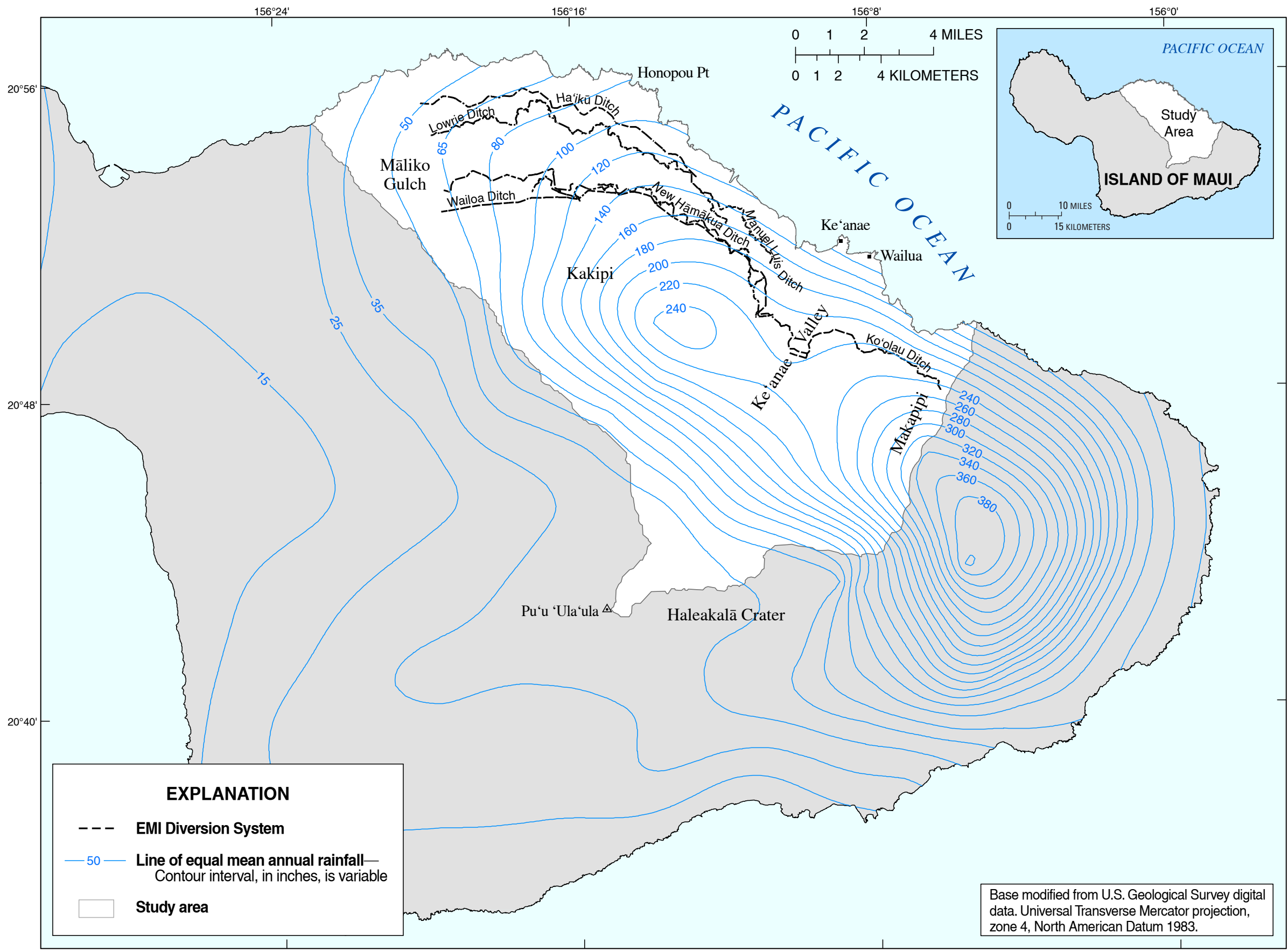

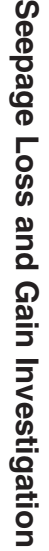

Figure 2. Mean annual rainfall, east Maui, Hawai'i (modified from Giambelluca and others, 2011). EMI, East Maui Irrigation. 
from stream diversions, and outflows from the ditch were typically flow releases to streams and reservoirs. Discharge measurements were made using Price pygmy and Price type AA vertical-axis current meters. All discharge measurements made as part of this study were entered into the USGS National Water Information System (NWIS) database and are available for online retrieval at http:// waterdata.usgs.gov/hi/nwis/nwis using USGS station numbers (see table 3).

\section{Ditch Characterization}

The lengths of EMI's four primary ditches and their connecting ditches are characterized as being either tunnel or open ditch on the basis of definitions summarized in figure 3. Lengths of ditch that are covered or underground, including culverts, siphons, and pipes, are categorized as tunnel. The construction types of tunnels are not identified in this study due to safety concerns associated with conducting surveys in confined spaces. Although the construction types at the tunnel entrances and exits are documented, those construction types may not be representative of the entire length of the tunnel. Openditch sections are further characterized by construction type, which is defined by the materials that make up the ditch walls and bottom. The three categories of open-ditch construction types are lined, partially lined, and unlined. Lined open-ditch sections have ditch walls and bottoms that are either concrete, stainless steel, solid bedrock, or cut stone with mortared joints-also known as armored cut-stone wall. A majority of the flumes are lined openditch sections because they are constructed entirely of concrete (fig. 4A) or stainless steel (fig. 4B) at the time of the study. Unlined open-ditch sections have walls and bottoms that consist of stacked rocks without mortared joints or any earthen material. Partially lined open-ditch sections have various combinations of lined and unlined ditch walls and bottoms, such as concrete-lined walls with an earthen bottom or an earthen bottom and wall with armored cut-stone on the other wall. Typically, partially lined open-ditch sections were at one time short unlined ditch sections that have been repaired.

Ditch characteristics of the EMI diversion system are mapped in the appendix and summarized in table 1. Photographs were taken to illustrate the various types of ditch characteristics identified in the EMI diversion system. Figure 1 shows the locations where the photographs included in figures 4 to 10 were taken. About 63 miles of the EMI diversion system were inspected in the field-73 percent of the system is tunnels and the remainder of the system is open ditches. Of the 17 miles of open ditches surveyed, about 65 percent is unlined, 21 percent is lined, and 14 percent is partially lined. EMI regularly maintains and repairs its diversion system, which may result in changes to the characteristics of each ditch over time. Therefore, the ditch characteristics documented in this report are representative of the EMI diversion system during the period of the study. The following is a summary of the ditch characteristics of each primary ditch system.

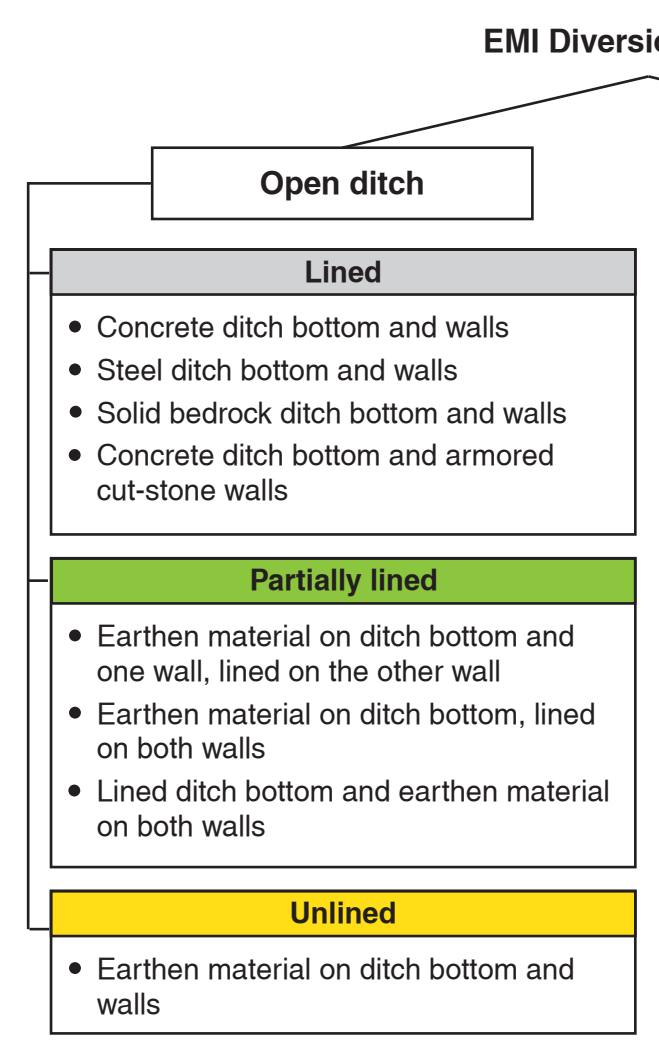

Figure 3. Ditch characterization of the East Maui Irrigation (EMI) diversion system, east Maui, Hawai'i. 
Ko 'olau and Wailoa Ditches._Ko'olau Ditch conveys water between Makapipi Stream and Alo Stream, a tributary of Waikamoi Stream, where the ditch is thereafter referred as Wailoa Ditch. Ko 'olau Ditch has a total length of 10.2 miles, 75 percent of which is tunnels and most of the remainder of which (about 2.5 miles) is lined open ditches that have concrete or armored cut-stone walls such as those shown in figure 5. From the start of the ditch at Makapipi Stream to Kopili ‘ula Stream, Ko'olau Ditch consists of a combination of tunnel and lined open-ditch sections. The remainder of the ditch between Kopili 'ula and Waikamoi Streams is entirely tunnel, except a short lined open-ditch section near Pi 'ina'au Stream. Heading west from Alo Stream, the Wailoa Ditch conveys water for about 9.6 miles mostly in tunnels and terminates at Māliko Gulch, where the water is delivered to the HC\&S plantation. The open-ditch sections of Wailoa Ditch are limited to concrete-lined flumes, one of which is illustrated in figure $4 A$.

Spreckels Ditch.-Not to be confused with Spreckels Ditch at Pāpa'a'ea or the Spreckels Ditch of west Maui, Spreckels Ditch of the EMI diversion system is located between altitudes of 1,210 and 1,760 ft. The ditch conveys water from Nua'ailua Stream to Alo Stream, where it discharges water to the Wailoa Ditch. Spreckels Ditch can also discharge water to Ko'olau Ditch by means of Kōlea Stream. Parts of Kōlea, Puohokamoa, and Haipua 'ena Streams convey water between sections of the Spreckels Ditch (fig. 6A). Excluding the streams that convey ditch water, Spreckels Ditch is about 3.6 miles in length, 2.0 miles of which are tunnels and 1.6 miles of which are a combination of short partially lined and unlined openditches (fig. 6B). At the time of the study, EMI was in the process of repairing the Spreckels Ditch and a portion of the water in the ditch was being discharged to Ko 'olau Ditch. Therefore, the ditch characteristics identified for Spreckels Ditch as part of this study may change once the repairs are complete.

New Hāmākua and Kauhikoa Ditches.-New Hāmākua and Kauhikoa Ditches are located immediately below the Wailoa Ditch between altitudes of 600 and 1,260 ft. The active parts of New Hāmākua Ditch extend from Alo Stream to Maka'a, Halehaku, and 'Ōpana Streams - tributaries of Kakipi Gulch. The section of New Hāmākua Ditch between 'Ōpana Stream and 'Ōpaepilau Gulch is abandoned and is therefore not characterized as part of this study. Excluding the stream conveyances, New Hāmākua Ditch is about 8.0 miles in length with 2.4 miles of open ditches and 5.6 miles of tunnels. About 60 percent of the open-ditch sections is unlined (fig. 7A), 36 percent is partially lined (fig. $7 B$ ), and the remainder is lined. New Hāmākua Ditch discharges water into the tributaries of Kakipi Gulch and subsequently into Kauhikoa Ditch. The Kauhikoa Ditch conveys water westward for about 5 miles almost entirely in tunnels to Māliko Gulch. One of the longest open-ditch sections of Kauhikoa Ditch is located near 'Ōpana Stream, where both ditch walls and the bottom are constructed of concrete (fig. 7C).

Spreckels Ditch at Pāpa 'a 'ea.-The shortest ditch in the EMI diversion system, Spreckels Ditch at Pāpa 'a 'ea, is located between altitudes of 680 and $930 \mathrm{ft}$. The ditch conveys water for about 1.0 mile from Ka'aiea Stream to Nailiilihaele Stream (the Hawaiian form of this stream name has not yet been verified), where the water is transferred to Lowrie Ditch. Near the end of Spreckels Ditch is Pāpa'a'ea Reservoir, which stores water mostly during periods of high rainfall. About 55 percent of Spreckels Ditch at Pāpa 'a'ea is unlined open-ditch sections with walls made of earthen material or stacked rocks and a gravel bottom (fig. 8A). Open-ditch sections at the diversion intakes are partially lined with armored cut-stone on one or both walls and have a gravel bottom (fig. $8 B$ ).

Manuel Luis, Center, and Lowrie Ditches.-The Manuel Luis, Center, and Lowrie Ditches are located below the New Hāmākua and Kauhikoa Ditches. Stream reaches are used to convey water between the three ditches, making them interconnected. Manuel Luis Ditch, located between altitudes of 720 and $940 \mathrm{ft}$, begins at Punalau Stream and extends to Waikamoi Stream, where the ditch water is transferred to Center Ditch. Reaches of Puohokamoa Stream convey ditch water between sections of the Manuel Luis Ditch. Excluding the stream reaches that convey ditch water, Manuel Luis Ditch is about 1.8 miles in length, about 1 mile of which is tunnels and the remainder of which is mostly unlined open ditches (fig. 9A). Center Ditch, located between altitudes of 660 and $740 \mathrm{ft}$, conveys water for 2.2 miles from Waikamoi Stream to Nailiilihaele Stream where the ditch water is transferred to Lowrie Ditch. About 69 percent of Center Ditch is tunnels, and the remaining 31 percent is mostly unlined open ditches (fig. 9B) with very few lined and partially lined open-ditch sections. Lowrie Ditch is the longest of the three ditches and it conveys water for 12.4 miles from Nailiilihaele Stream near an altitude of $680 \mathrm{ft}$ to Māliko Gulch near an altitude of $280 \mathrm{ft}$. About 4.6 miles (37 percent) of the ditch is tunnels and the remaining 7.8 miles is mostly unlined open ditches. The unlined open-ditch sections of the Manuel Luis and Center Ditches are very similar with gravel bottoms and walls made of earthen material on one side and stacked rocks on the other, whereas those of the Lowrie Ditch have mostly earthen walls and bottoms (fig. $9 C$ ). Lowrie Ditch had one of the last remaining wood flumes of the EMI diversion system, and it was replaced in October 2011 with a stainless-steel flume (fig. 9D) (Garret Hew, EMI, oral commun., November 22, 2011).

Ha 'iku Ditch.-Ha'ikū Ditch is located at the lowest altitude of all the ditches in the EMI diversion system. It conveys water for 9.7 miles from Kailua Stream to Māliko Gulch almost entirely by tunnels. Open-ditch sections constitute only about 0.4 miles of the Ha'ikū Ditch, and they are limited to concrete flumes (fig. 10) and lined diversion intakes. 
Table 1. Summary of ditch characteristics for the East Maui Irrigation diversion system, east Maui, Hawai'i.

[Approximate ditch lengths in miles. Sum of individual lengths may not add up to total due to rounding]

\begin{tabular}{|c|c|c|c|c|c|}
\hline \multirow[b]{2}{*}{ Ditch system } & \multirow{2}{*}{$\begin{array}{c}\text { Total length } \\
\text { of ditch }\end{array}$} & \multirow[b]{2}{*}{ Tunnel } & \multicolumn{3}{|c|}{ Open ditch } \\
\hline & & & Lined & $\begin{array}{l}\text { Partially } \\
\text { lined }\end{array}$ & Unlined \\
\hline Ko`olau & 10.20 & 7.70 & 2.47 & 0.02 & 0 \\
\hline Wailoa & 9.56 & 9.49 & 0.07 & 0 & 0 \\
\hline Spreckels & 3.58 & 2.00 & 0.01 & 1.28 & 0.29 \\
\hline New Hāmākua & 8.05 & 5.61 & 0.13 & 0.86 & 1.44 \\
\hline Kauhikoa & 4.96 & 4.78 & 0.16 & 0.02 & 0 \\
\hline Spreckels at Pāpa'a'ea & 1.04 & 0.42 & 0.01 & 0.03 & 0.57 \\
\hline Manuel Luis & 1.79 & 0.97 & 0 & 0.06 & 0.76 \\
\hline Center & 2.20 & 1.51 & 0.11 & 0.04 & 0.54 \\
\hline Lowrie & 12.41 & 4.61 & 0.21 & 0.13 & 7.46 \\
\hline Ha ‘ikū & 9.68 & 9.30 & 0.38 & 0 & 0 \\
\hline Total & 63.47 & 46.41 & 3.53 & 2.45 & 11.08 \\
\hline
\end{tabular}

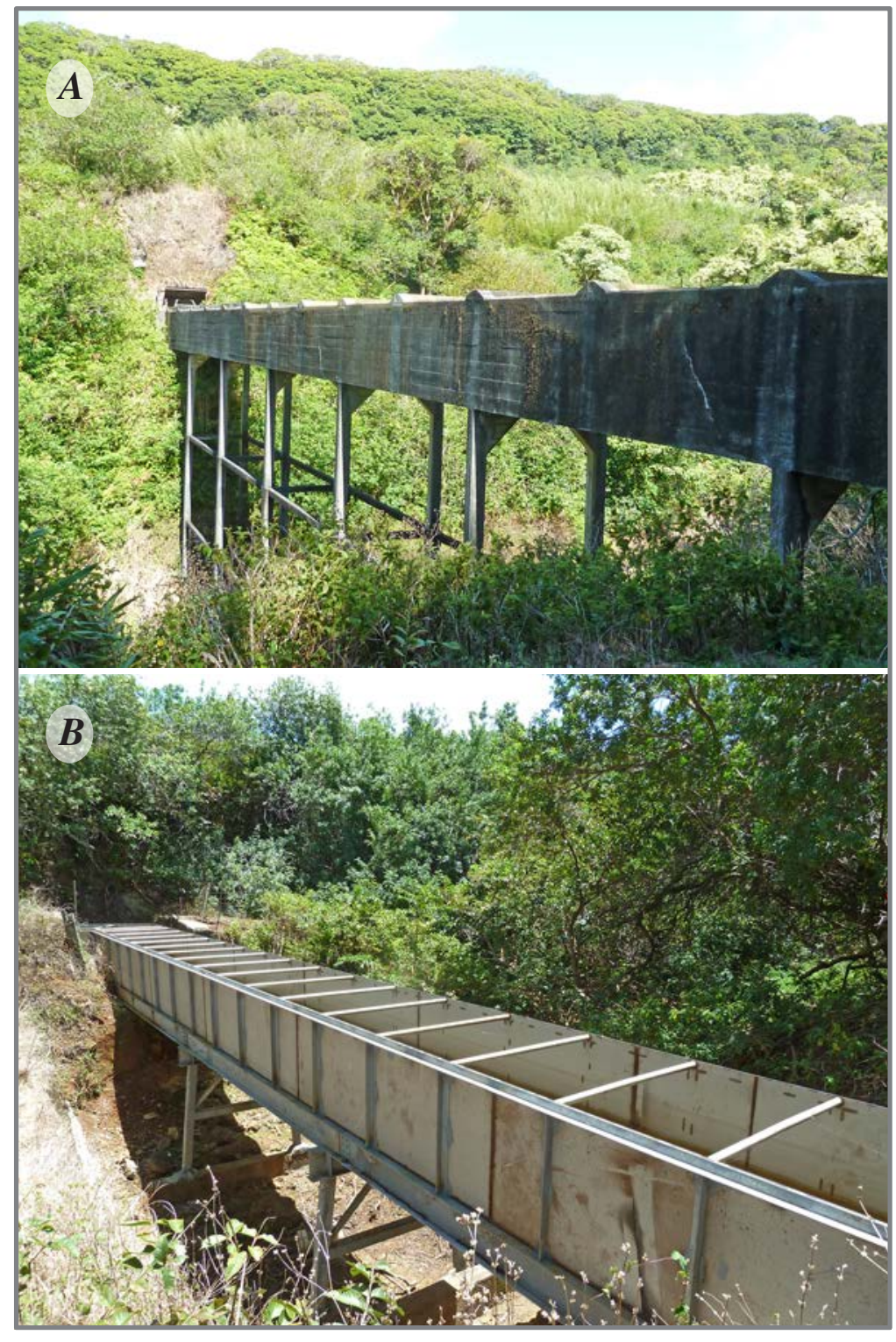

Figure 4. Photographs of two flumes that are part of the East Maui Irrigation diversion system, east Maui, Hawai'i. $A$, Concrete-lined flume along the Wailoa Ditch at 'Ōpana. B, Stainless-steel flume along the Lowrie Ditch near Kuiaha Gulch, also known as Labasan flume. 


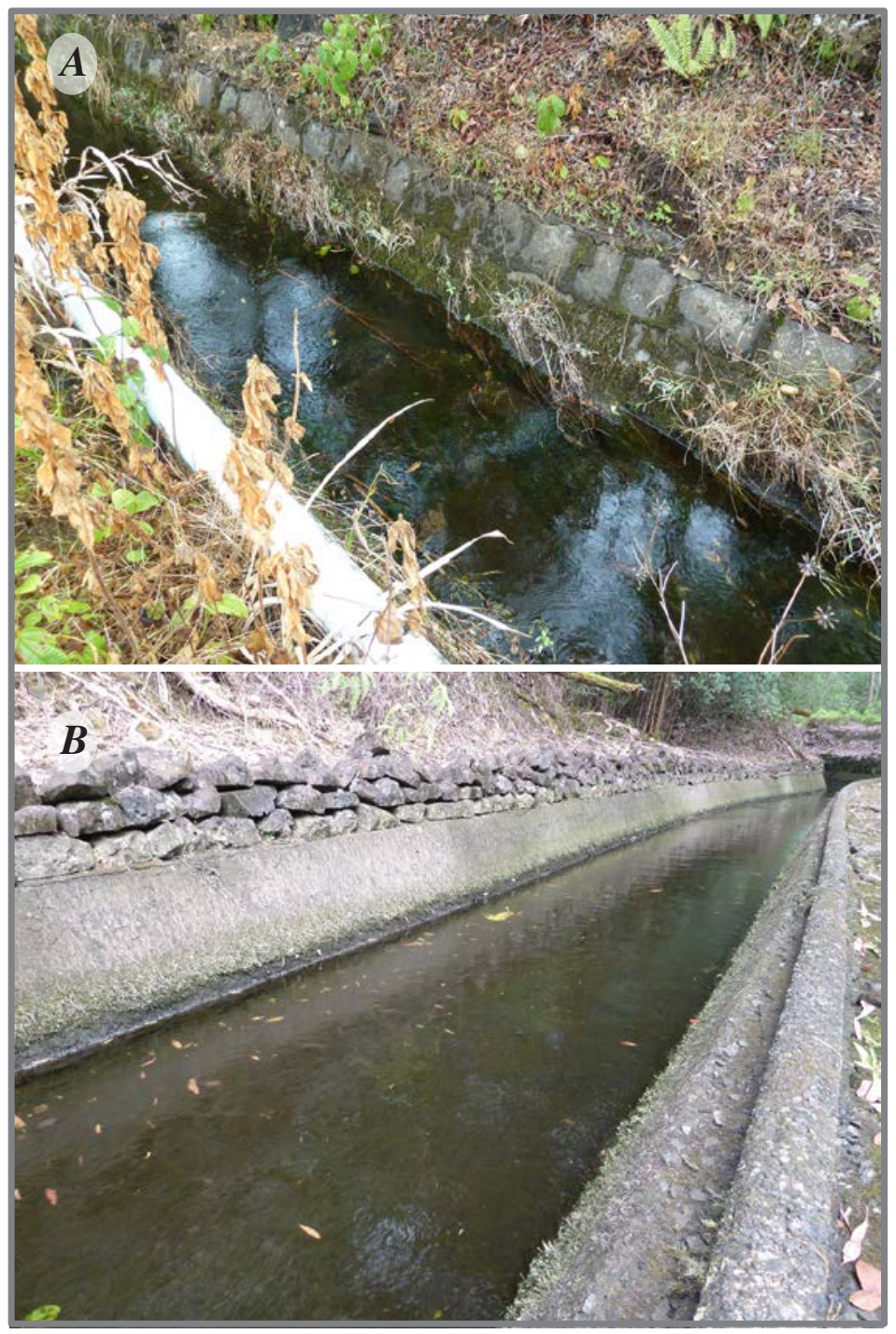

Figure 5. Photographs of two sections of the Ko'olau Ditch, East Maui Irrigation diversion system, east Maui, Hawai'i. A, Lined open-ditch section near Makapipi Stream with armored cut-stone walls and concrete bottom. $B$, Lined open-ditch section near Waiohue Stream with concrete walls and bottom.
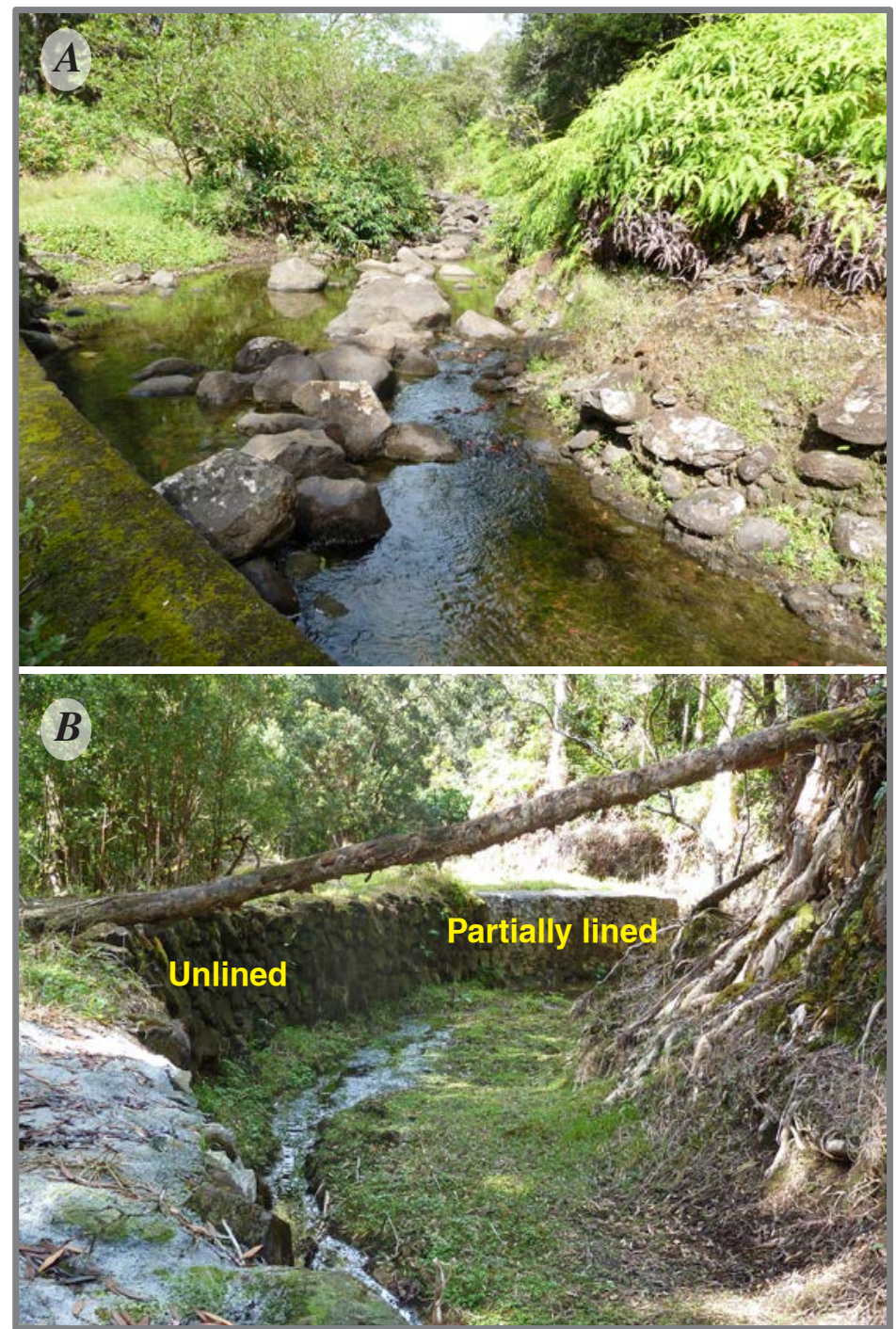

Figure 6. Photographs of two sections of the Spreckels Ditch, East Maui Irrigation diversion system, east Maui, Hawai'i. $A$, Haipua'ena Stream used as ditch-water conveyance. $B$, An open-ditch section that is both unlined and partially lined. 

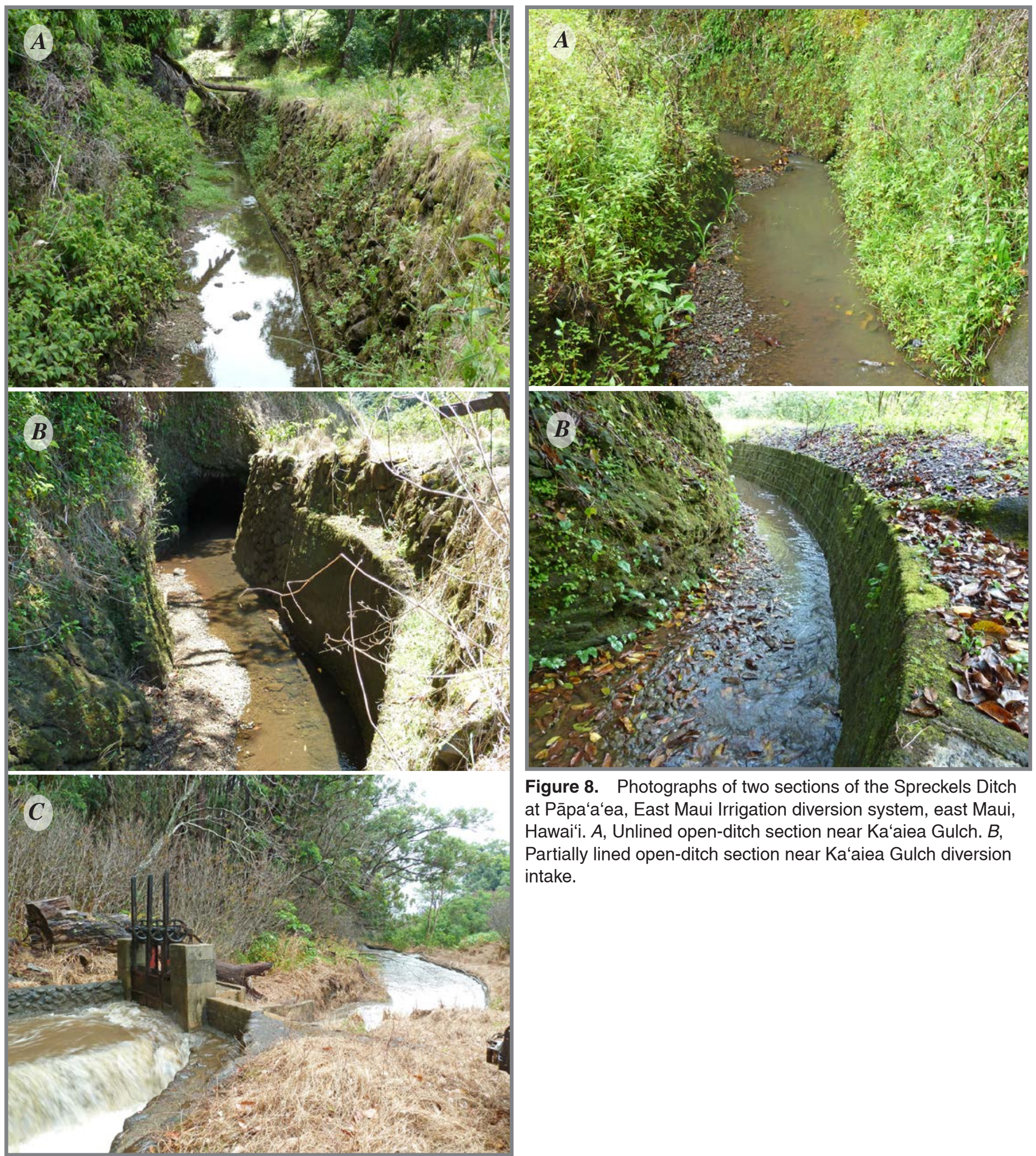

Figure 8. Photographs of two sections of the Spreckels Ditch at Pāpa'a'ea, East Maui Irrigation diversion system, east Maui, Hawai'i. A, Unlined open-ditch section near Ka'aiea Gulch. B, Partially lined open-ditch section near Ka'aiea Gulch diversion intake.

Figure 7. Photographs of three sections of the New Hāmākua and

Kauhikoa Ditches, East Maui Irrigation diversion system, east Maui, Hawai'i. $A$, New Hāmākua Ditch, unlined open-ditch section at 'O'opuola Stream. $B$, New Hāmākua Ditch, partially lined open-ditch section near Waipi'o Stream. $C$, Kauhikoa Ditch, lined open-ditch section at 'Ōpana Stream. 


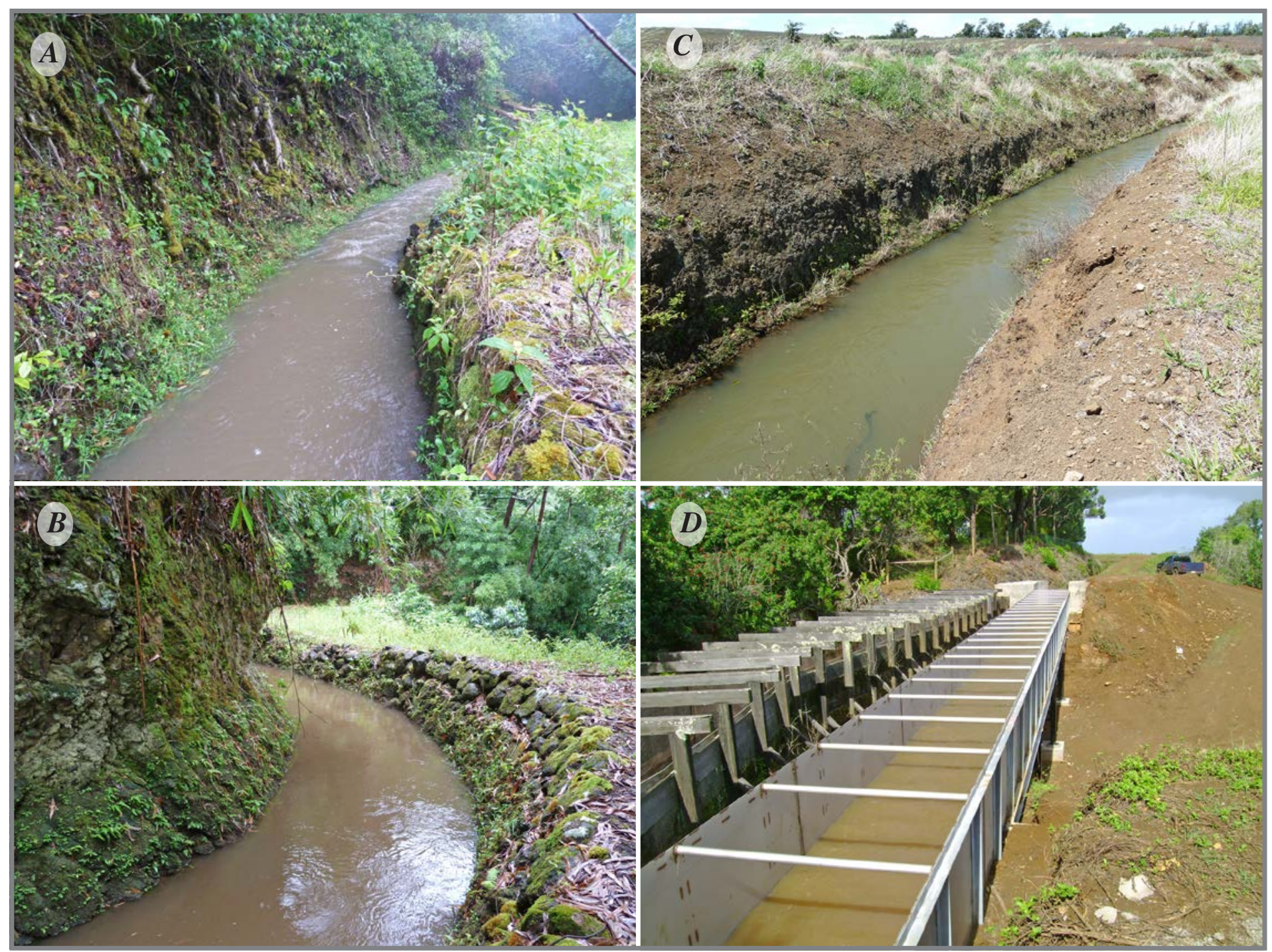

Figure 9. Photographs of Manuel Luis, Center, and Lowrie Ditches, East Maui Irrigation diversion system, east Maui, Hawai'i. $A$, Manuel Luis Ditch, unlined open-ditch section near Puohokamoa Stream. B, Center Ditch, unlined open-ditch section between Kōlea and Punalu'u Streams. C, Lowrie Ditch, unlined open-ditch section near Māliko Gulch. D, Lowrie Ditch, old wood flume and replacement stainless-steel flume near Pe‘ahi Reservoir (photograph by Garret Hew, East Maui Irrigation Company). 

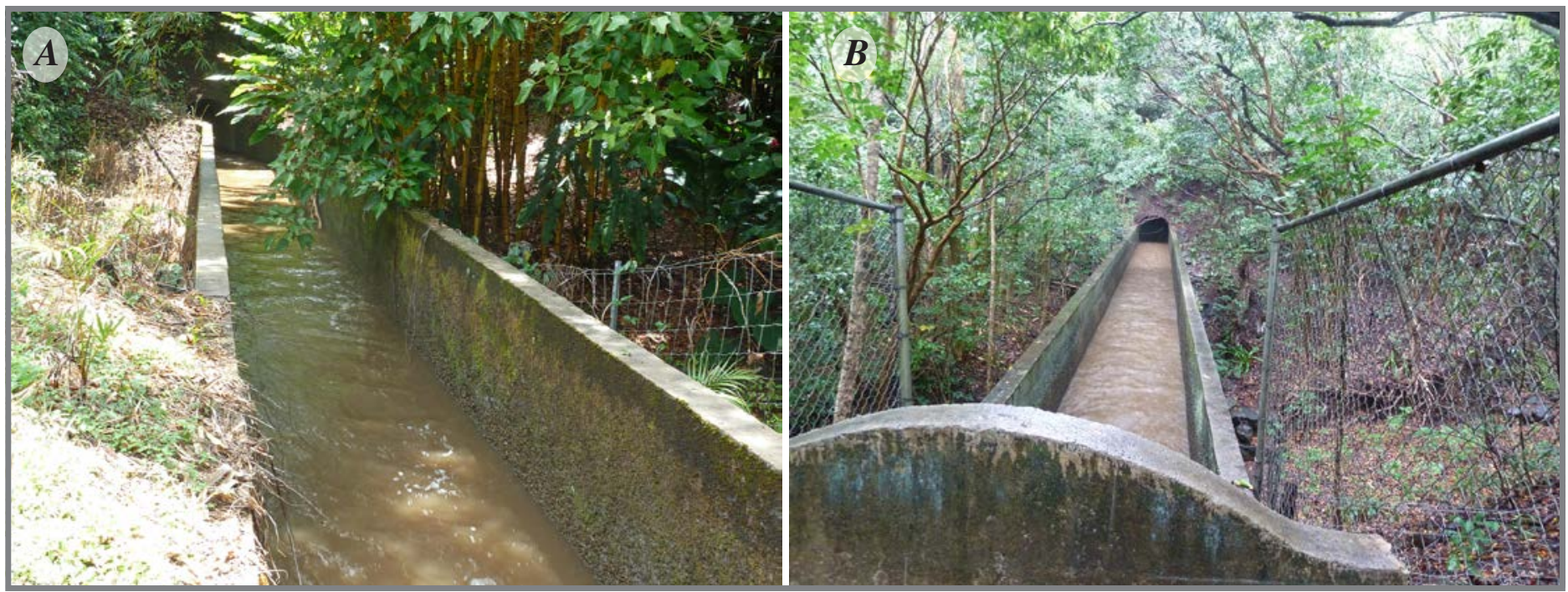

Figure 10. Photographs of two sections of the Ha'ikū Ditch, East Maui Irrigation diversion system, east Maui, Hawai'i. A, Eby Flume at Manawaiiao Stream. B, Shirota Flume at Kuiaha Gulch.

\section{Seepage Runs}

A seepage run in a diversion system consists of making multiple discharge measurements at nearly the same time along the selected reach. These same-day discharge measurements can be used to estimate seepage loss and gain rates over the measurement reaches. Conducting seepage runs in a diversion system is challenging because both natural (variations in rainfall and streamflow) and human (diversionsystem manipulations) factors can result in changing flow conditions. Flow in a ditch is affected by inflows from multiple stream diversion intakes and outflows into other ditches and streams. Given the frequent rainfall in the study area, surface runoff and overflow ditches that convey water from one ditch to another could very quickly affect flow in the entire EMI diversion system. In some cases, rainfall may only affect flows in the upper ditches, while flows in the lower ditches remain relatively stable. Furthermore, regular maintenance and repair of the EMI diversion system may disrupt ditch flow and restrict access into certain areas. These potential alterations in flow present complications when scheduling and conducting seepage runs.

Within the EMI diversion system, seepage-run measurement reaches were chosen on the basis of the following criteria: (1) reaches are representative of the different characteristics identified during the field inspections along each of the ditches; (2) reaches are as long as possible to increase the possibility of measuring representative seepage losses or gains and to minimize the effects of anomalous localized conditions on the overall average seepage rates; and (3) reaches have minimal or no additional diversion inflows and outflows, thereby reducing the inherent error introduced with each additional measurement that is required to characterize seepage rates within the measurement reaches. Seepage runs were not conducted in Spreckels Ditch because EMI was repairing the ditch at the time of the study.

Seepage runs were done on days when flow was generally stable in the ditch reaches where discharge measurements were made. Stable flow conditions were documented by recording the height of water surface, commonly referred to as gage height or stage, during the time when discharge measurements were being made. Whether a change in stage causes a substantial change in flow depends on the geometry and slope of the ditch in the vicinity of the cross section where the discharge measurement is being made, as well as the magnitude of flow. In some cases, discharges in the lower ditches were measured just before a change in flow condition was detected because the stage was continuously monitored during the discharge measurements. Depending on the number of diversion inflows and outflows and the need for repeat discharge measurements, a total of two to five discharge measurements were made at each seepage-run measurement reach at nearly the same time on the same day. Seepage losses and gains within the measurement reaches that were visually detected were estimated by a field technician if the flows were too low to measure with the available instruments.

Each discharge measurement made for this study was assigned one of four ratings-excellent, good, fair, or poor. The rating of a discharge measurement is a subjective evaluation of the measurement made by the field technician. The purpose of the rating is to qualitatively account for some of the factors that could potentially affect the accuracy of the discharge measurement. These factors include, but are not limited to, the condition of the 
measuring instrument, characteristics of the measurement cross section, spacing and number of observation verticals in a measurement cross section, changing stage, measurement of depth and velocity, and environment (Rantz and others, 1982, p. 179-80). Discharge measurements made during this study were generally rated good or fair, with a few measurements rated poor because of the characteristics of the measurement cross section.

Replicate measurements were made immediately following the first measurement at a number of randomly selected seepage-run discharge-measurement stations. This was done to address uncertainty associated with factors affecting the accuracy of a discharge measurement. Repeating the discharge measurement under changing measurement conditions - that is, different field technician, instrument, and (or) measurement cross section-could potentially reduce that uncertainty (Turnipseed and Sauer, 2010; Rantz and others, 1982). According to the USGS Pacific Islands Water Science Center surface-water quality-assurance standards (Ronald Rickman, USGS, written commun., January 14, 2011), if the first measurement and the replicate measurement are made under stable flow conditions, the difference between the two measurements should satisfy at least one of two criteria. The first criterion, associated with the magnitude of the discharge, indicates that the difference between the replicate measurements should be (1) within 10 percent for discharges less than 1.0 cubic feet per second $\left(\mathrm{ft}^{3} / \mathrm{s}\right),(2)$ within 7 percent for discharges of 1.0 through $10.0 \mathrm{ft}^{3} / \mathrm{s}$, and (3) within 5 percent for discharges greater than $10.0 \mathrm{ft}^{3} / \mathrm{s}$. The second criterion, associated with the accuracy rating assigned to the replicate measurements, indicates that the difference should be (1) within 5 percent for measurements rated good to excellent, (2) within 8 percent for measurements rated fair; and (3) within 10 percent for measurements rated poor. For those cases in which one of the two criteria was satisfied, the average of the first measurement and the replicate measurement(s) is used to represent the discharge at the seepage-run station. For cases in which the difference between the measurements does not fall within the percentages listed above, an additional measurement is made and the outlier measurement is not used in computing the average discharge.

\section{Seepage Losses and Gains}

Efficiency of a diversion system describes its function and performance in regards to the transport and (or) storage of the diverted water. For a well-maintained irrigationwater diversion system, seepage gains are typically favored and repairs are done to reduce the amount of seepage losses. Generally, seepage losses would be expected to be the highest for ditch reaches with large wetted perimeter (ditch surface in direct contact with water) and head (depth of water), all other factors being equal. If a ditch is not maintained properly and repairs are not made expeditiously to sections of the ditch in poor condition, the ditch condition would likely continue to degrade and seepage losses could increase over time. Seepage losses may also vary by irrigation season based on the length of time that the ditches transport water. The overflow ditches_-New Hāmākua and Ha 'ikū Ditch-sometimes run dry in the summer months when irrigation demand is high and available surface water is low. In this case, seepage losses may be more pronounced during initial wetting when flow in the ditches resumes.

The seepage loss or gain for each seepage-run measurement reach was computed as the difference between the downstream and upstream discharges, excluding any estimated or measured diversion inflows and outflows within the reach. The length of the seepage-run measurement reach was estimated from the USGS topographic map for east Maui as the horizontal distance in map view, using geographic information system (GIS) software. Seepage rate, expressed in cubic feet per second per mile of ditch $\left(\mathrm{ft}^{3} / \mathrm{s} / \mathrm{mi}\right)$, is the ratio of estimated loss or gain to the length of the seepagerun measurement reach. The seepage rates are specific to the seepage-run measurement reaches where discharges were measured. The magnitude of the seepage loss or gain in a reach relative to the discharges in the reach may provide insight into the potential uncertainty in the estimated seepage loss or gain. In some instances, the estimated seepage losses and gains fall within the standard of error associated with the accuracy of the discharge measurements. For these cases, estimated seepage rates may represent the true seepage loss or gain within the measurement reaches. However, it is also possible that these seepage rates may reflect uncertainty in the discharge measurements.

About 15 miles of seepage-run measurement reaches were selected, 9 miles of which are open ditches and the remainder of which are tunnels (table 2). Seepage losses and gains were determined for about 52 percent of the 17 miles of open ditches identified during the ditch characteristics field inspections. Ditch characteristics for each of the seepage-run measurement reaches are shown in the appendix. Excluding Spreckels Ditch, where no seepage runs were conducted because of ongoing maintenance and repair, six out of the nine ditches that are part of the EMI diversion system have more than half of their identified open-ditch reaches measured in seepage runs. Wailoa, Kauhikoa, and Ha'ikū Ditches have fewer open-ditch seepage-run measurement reaches because the ditches are mostly tunnels. Seepage runs in partially lined open-ditch reaches are limited, because these types of ditch reaches typically exist in very short reaches at diversion intakes and areas where repairs have been made. For this study, a total of 55 seepage-run discharge-measurement stations (table 3) were established, and 87 discharge measurements were made during a period of 11 days in June, August, and September of 2011. Table 4 lists the seepage-run measurement reaches and their associated discharge measurements, seepage loss and gain estimates, length of the measurement reach, and seepagerate estimates. An abbreviated station identifier (station ID) is assigned to each seepage-run discharge-measurement station for ease of reference in the report. The station ID is composed 
Table 2. Summary of ditch characteristics for seepage-run measurement reaches of the East Maui Irrigation diversion system, east Maui, Hawai'i.

[Approximate ditch lengths in miles; --, seepage run not conducted on Spreckels Ditch. Sum of individual lengths may not add up to total due to rounding]

\begin{tabular}{lccccc}
\hline \multirow{2}{*}{ Ditch system } & $\begin{array}{c}\text { Total length of } \\
\text { measurement } \\
\text { reach }\end{array}$ & Tunnel & & \multicolumn{3}{c}{ Open ditch } \\
\cline { 5 - 6 } & 1.44 & 0.10 & 1.34 & 0 & 0 \\
\hline Ko'olau & 0.59 & 0.57 & 0.02 & 0 & 0 \\
Wailoa & -- & -- & -- & -- & -- \\
Spreckels & 1.97 & 1.00 & 0 & 0.23 & 0.75 \\
New Hāmākua & 1.61 & 1.51 & 0.08 & 0.02 & 0 \\
Kauhikoa & 0.43 & 0.08 & 0 & 0.03 & 0.32 \\
Spreckels at Pāpa'a'ea & 0.93 & 0.53 & 0 & 0.02 & 0.38 \\
Manuel Luis & 0.86 & 0.39 & 0 & 0.03 & 0.45 \\
Center & 6.05 & 1.02 & 0.05 & 0.08 & 4.90 \\
Lowrie & 0.84 & 0.73 & 0.11 & 0 & 0 \\
Ha'ikū & 14.72 & 5.93 & 1.60 & 0.41 & 6.79 \\
\hline Total & & & & & Unlined \\
\hline
\end{tabular}

a Total length of ditch excludes abandoned ditch sections and streams used for ditch-water conveyance.

Table 3. Seepage-run discharge-measurement stations on the East Maui Irrigation diversion system, east Maui, Hawaii

[Station ID, station identifier that is also referenced in table 4; USGS, U.S. Geological Survey; NWIS, National Water Information System; DS, downstream; US, upstream; nr, near; Rd, road]

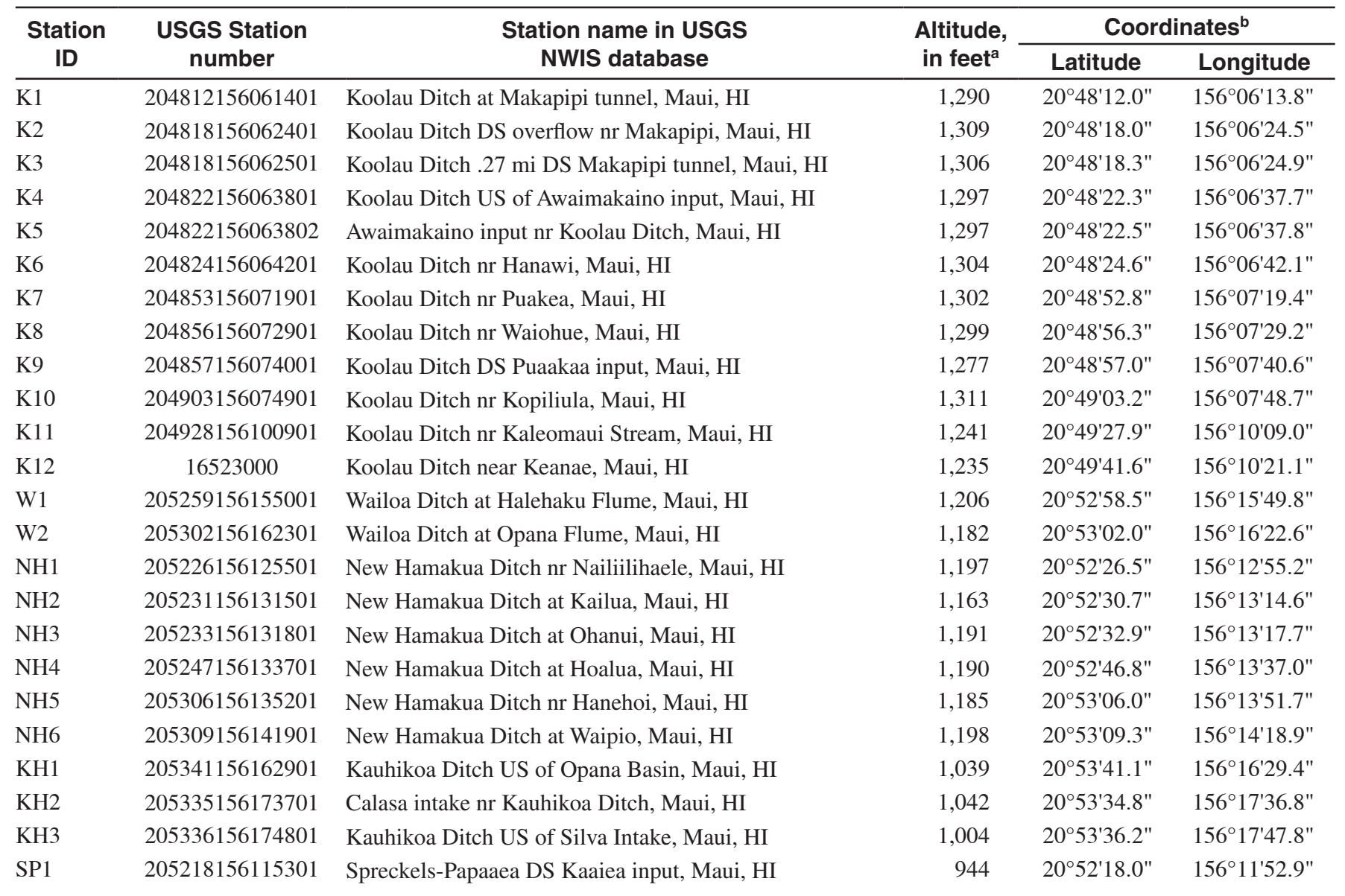


Table 3. Seepage-run discharge-measurement stations on the East Maui Irrigation diversion system, east Maui, Hawai'i. -Continued

[Station ID, station identifier that is also referenced in table 4; USGS, U.S. Geological Survey; NWIS, National Water Information System; DS, downstream; US, upstream; nr, near; Rd, road]

\begin{tabular}{|c|c|c|c|c|c|}
\hline \multirow{2}{*}{$\begin{array}{l}\text { Station } \\
\text { ID }\end{array}$} & \multirow{2}{*}{$\begin{array}{l}\text { USGS Station } \\
\text { number }\end{array}$} & \multirow{2}{*}{$\begin{array}{c}\text { Station name in USGS } \\
\text { NWIS database }\end{array}$} & \multirow{2}{*}{$\begin{array}{l}\text { Altitude, } \\
\text { in feet }^{\mathrm{a}}\end{array}$} & \multicolumn{2}{|c|}{ Coordinates $^{b}$} \\
\hline & & & & Latitude & Longitude \\
\hline SP2 & 205226156115801 & Spreckels-Papaaea US Makanali input, Maui, HI & 944 & $20^{\circ} 52^{\prime} 26.2^{\prime \prime}$ & $156^{\circ} 11^{\prime} 58.1^{\prime \prime}$ \\
\hline SP3 & 205241156121501 & Spreckels-Papaaea nr Oopuola, Maui, HI & 839 & $20^{\circ} 52^{\prime} 41.2^{\prime \prime}$ & $156^{\circ} 12^{\prime} 15.3^{\prime \prime}$ \\
\hline SP4 & 205247156121401 & Spreckels-Papaaea at Papaaea flume, Maui, HI & 831 & $20^{\circ} 52^{\prime} 47.2^{\prime \prime}$ & $156^{\circ} 12^{\prime} 14.0^{\prime \prime}$ \\
\hline ML1 & 205126156103801 & Manuel Luis Ditch nr Punalau, Maui, HI & 953 & $20^{\circ} 51 ' 25.8^{\prime \prime}$ & $156^{\circ} 10^{\prime} 38.5^{\prime \prime}$ \\
\hline ML2 & 16541500 & Manuel Luis Ditch at Puohokamoa Stream, Maui, HI & 910 & $20^{\circ} 51 ' 36.2^{\prime \prime}$ & $156^{\circ} 10^{\prime} 49.2^{\prime \prime}$ \\
\hline ML4 & 205152156110501 & Manuel Luis Ditch nr Wahinepee Rd, Maui, HI & 913 & $20^{\circ} 51 ' 51.6 "$ & $156^{\circ} 11^{\prime} 05.4^{\prime \prime}$ \\
\hline ML5 & 205203156111401 & Manuel Luis Ditch DS Wahinepee input, Maui, HI & 892 & $20^{\circ} 52^{\prime} 03.2^{\prime \prime}$ & $156^{\circ} 11^{\prime} 13.8^{\prime \prime}$ \\
\hline ML6 & 205212156112001 & Manuel Luis Ditch nr Waikamoi, Maui, HI & 746 & $20^{\circ} 52^{\prime} 12.4^{\prime \prime}$ & $156^{\circ} 11^{\prime} 20.4^{\prime \prime}$ \\
\hline $\mathrm{C} 1$ & 205222156112401 & Center Ditch DS of Kolea input, Maui, HI & 747 & $20^{\circ} 52 ' 22.4^{\prime \prime}$ & $156^{\circ} 11^{\prime} 24.2^{\prime \prime}$ \\
\hline $\mathrm{C} 2$ & 205241156113301 & Center Ditch US of Punaluu input, Maui, HI & 719 & $20^{\circ} 52^{\prime} 41.5^{\prime \prime}$ & $156^{\circ} 11^{\prime} 33.5^{\prime \prime}$ \\
\hline L2 & 205341156130901 & Lowrie Ditch nr Hoalua, Maui, HI & 666 & $20^{\circ} 53^{\prime} 41.0^{\prime \prime}$ & $156^{\circ} 13^{\prime} 08.7^{\prime \prime}$ \\
\hline L3 & 205342156131301 & Lowrie Ditch DS Hoalua intake, Maui, HI & 640 & $20^{\circ} 53^{\prime} 41.7 "$ & $156^{\circ} 13^{\prime} 12.5^{\prime \prime}$ \\
\hline L4 & 205342156132401 & Lowrie Ditch US Hanehoi intake, Maui, HI & 628 & $20^{\circ} 53^{\prime} 42.3^{\prime \prime}$ & $156^{\circ} 13^{\prime} 24.1^{\prime \prime}$ \\
\hline L5 & 205417156144001 & Lowrie Ditch DS Hoolawanui intake, Maui, HI & 618 & $20^{\circ} 54^{\prime} 17.4^{\prime \prime}$ & $156^{\circ} 14^{\prime} 39.6^{\prime \prime}$ \\
\hline L6 & 205435156145801 & Lowrie Ditch US Honopou intake, Maui, HI & 599 & $20^{\circ} 54^{\prime} 35.0^{\prime \prime}$ & $156^{\circ} 14^{\prime} 57.7^{\prime \prime}$ \\
\hline L7 & 205437156150101 & Lowrie Ditch DS siphon at Honopou, Maui, HI & 613 & $20^{\circ} 54 ' 37.2^{\prime \prime}$ & $156^{\circ} 15^{\prime} 00.7^{\prime \prime}$ \\
\hline L8 & 205438156153101 & Lowrie Ditch US Kapalaalea input, Maui, HI & 603 & $20^{\circ} 54 ' 38.1 "$ & $156^{\circ} 15^{\prime} 31.1^{\prime \prime}$ \\
\hline L9 & 205509156163502 & Peahi flume leak nr Lowrie Ditch, Maui, HI & 563 & $20^{\circ} 55^{\prime} 08.8^{\prime \prime}$ & $156^{\circ} 16^{\prime} 35.4^{\prime \prime}$ \\
\hline L10 & 205509156163501 & Lowrie Ditch DS of Peahi flume, Maui, HI & 562 & $20^{\circ} 55^{\prime} 09.1 "$ & $156^{\circ} 16^{\prime} 35.0^{\prime \prime}$ \\
\hline L11 & 205453156172801 & Lowrie Ditch nr Kaupakulua, Maui, HI & 593 & $20^{\circ} 54 ' 53.5^{\prime \prime}$ & $156^{\circ} 17^{\prime} 28.4^{\prime \prime}$ \\
\hline $\mathrm{H} 5$ & 205522156184101 & Haiku Ditch at Shirota Flume, Maui, HI & 309 & $20^{\circ} 55^{\prime} 22.1^{\prime \prime}$ & $156^{\circ} 18^{\prime} 40.8^{\prime \prime}$ \\
\hline
\end{tabular}

${ }^{a}$ Altitude values interpolated from USGS 1:24,000-scale digital hypsography data.

${ }^{\mathrm{b}}$ Latitude and longitude coordinates in North American Datum of 1983.

of one to two letters representing the ditch, followed by a number indicating the location of the station relative to its adjacent stations-for example, station $\mathrm{K} 1$ is four stations upstream from station K5 along Ko'olau Ditch. For seepage-run discharge-measurement stations with replicate measurements, the average of all discharge measurements were used to compute seepage losses and gains except at station ML4 in which only the second and third discharge measurements were used because those two measurements were most consistent.

Ko'olau and Wailoa Ditches. - A total of six seepagerun measurement reaches, which consist mainly of lined open ditches, were selected along the Ko 'olau Ditch. Discharge measurements were made on June 13-14 and September 12, 2011, and the discharges ranged from $2.34 \mathrm{ft}^{3} / \mathrm{s}$ near Hanawi Stream (station K4) to $44.4 \mathrm{ft}^{3} / \mathrm{s}$ near Ke'anae (station K11). Estimated seepage rates generally showed losses that ranged from 0.94 to $3.0 \mathrm{ft}^{3} / \mathrm{s} / \mathrm{mi}$, except in the 0.20 -mile reach between stations $\mathrm{K} 9$ and $\mathrm{K} 10$ that had a seepage-gain rate of $3 \mathrm{ft}^{3} / \mathrm{s} / \mathrm{mi}$ as shown by discharge measurements made on June 14, 2011. Seepage losses and gains for three of the seepage-run measurement reaches were within 5 percent of the upstream discharges in the measurement reaches. Two seepage runs-from stations K1 to K2 and K9 to 
K10-were repeated because the differences between the upstream and downstream discharges from the first set of discharge measurements were relatively large, and they departed from the general range of seepage losses and gains observed at the other measurement reaches. A second set of measurements was made for those seepage-run measurement reaches, and the seepage rates estimated from the second set of discharge measurements fell within the general range of seepage losses and gains. The seepage rates associated with the initial seepage runs (June 13, 2011) between K1 and $\mathrm{K} 2$ and between $\mathrm{K} 9$ and $\mathrm{K} 10$ may reflect instrument error, measurement error, or unexpected changes at the diversion structures that affected the ditch flow for a short period of time. Additional measurements in these reaches would reduce uncertainty in estimated seepage rates.

Wailoa Ditch has only one seepage-run measurement reach because the ditch is almost entirely tunnel with very few open-ditch sections where discharge measurements could be made. Wailoa Ditch typically transports a majority of the diverted water in the EMI diversion system and it has an average flow of $110 \mathrm{Mgal} / \mathrm{d}$ (Gingerich, 1999, p. 15). The discharges measured on September 13, 2011, indicated a flow of about $88 \mathrm{ft}^{3} / \mathrm{s}$ at the concrete flume near 'Ōpana Stream. Discharge measurements made for this study showed a seepage-gain rate of $5.2 \mathrm{ft}^{3} / \mathrm{s} / \mathrm{mi}$ between station $\mathrm{W} 1$ at Halehaku flume and station W2 at 'Ōpana flume. The seepage gain was within 5 percent of the upstream discharge in the measurement reach.

New Hāmākua and Kauhikoa Ditches.-The three seepage-run measurement reaches of the New Hāmākua Ditch are mostly tunnels and unlined open-ditches. Partially lined open-ditch reaches are located at the diversion intakes, which were not diverting water at the time of the seepage runs. Kauhikoa Ditch has only one seepage-run measurement reach, generally of tunnel construction, because the ditch has very few open-ditch sections where discharge measurements could be made. Discharge measurements for New Hāmākua Ditch made on August 10, 2011, ranged from $0.52 \mathrm{ft}^{3} / \mathrm{s}$ near Nailiilihaele (station NH1) to $1.15 \mathrm{ft}^{3} / \mathrm{s}$ near Hanehoi (station NH5) and at Waipi 'o (station NH6). Estimated seepage rates showed gains that ranged from 0.04 to 0.49 $\mathrm{ft}^{3} / \mathrm{s} / \mathrm{mi}$ within the seepage-run measurement reaches. Only one out of the three measurement reaches had seepage gains within 5 percent of the upstream discharge in the measurement reach. Discharges measured in Kauhikoa Ditch on September 13, 2011, showed a seepage-gain rate of about $0.20 \mathrm{ft}^{3} / \mathrm{s} / \mathrm{mi}$ between station KH1 near 'Ōpana Stream and station KH3 near East Kuiaha Gulch.

Spreckels Ditch at Pāpa 'a 'ea.-The Spreckels Ditch at Pāpa'a'ea has two seepage-run measurement reaches, and they are almost entirely unlined open ditches. Both sets of discharge measurements made on June 16, 2011, indicated seepage losses.

Manuel Luis, Center, and Lowrie Ditches.-The Manuel Luis Ditch has three seepage-run measurement reaches, and they are mainly tunnel and unlined open ditches. Discharge measurements made on June 15, 2011, ranged from $0.24 \mathrm{ft}^{3} / \mathrm{s}$ near Puohokamoa Stream near the beginning of the ditch (station ML2) to $1.19 \mathrm{ft}^{3} / \mathrm{s}$ near Waikamoi Stream (station ML6) upstream of where ditch water is conveyed to Center Ditch. Seepage rates were variable, with both losses and gains throughout the seepage-run measurement reaches. The largest estimated seepage-loss rate was $0.3 \mathrm{ft}^{3} / \mathrm{s} / \mathrm{mi}$ between stations ML1 and ML2, a reach that was almost all tunnel construction.

The two seepage-run measurement reaches selected for the Center Ditch are mostly tunnel and unlined open ditches. Discharge measurements made on June 16, 2011, varied between $3.24 \mathrm{ft}^{3} / \mathrm{s}$ near Kōlea Stream (station C1) and $4.03 \mathrm{ft}^{3} / \mathrm{s}$ near Makanali Stream (station C3). The discharge measurements showed a seepage-gain rate of $0.45 \mathrm{ft}^{3} / \mathrm{s} / \mathrm{mi}$ in the upstream measurement reach (stations $\mathrm{C} 1$ to $\mathrm{C} 2$ ) and a seepage-loss rate of $1.1 \mathrm{ft}^{3} / \mathrm{s} / \mathrm{mi}$ at the downstream measurement reach (stations C3 to C4). The seepage flows were within 8 percent of the upstream discharges in the measurement reaches.

Lowrie Ditch has six seepage-run measurement reaches, and they are mostly unlined open ditches, except the reach between stations L1 and L2 that is mostly tunnel. Seepage runs were made before the Pe'ahi flume was replaced with a stainless-steel flume (fig. 9D); therefore, flume leakage measurements at station L9 no longer apply to the current condition of the flume. A seepage run on Lowrie Ditch was attempted on June 17, 2011 and was aborted due to heavy rain. Successful seepage-run discharge measurements were made on August 8-9, 2011, and the flows varied between 15.2 $\mathrm{ft}^{3} / \mathrm{s}$ near Kailua Stream (station L1) and $41.3 \mathrm{ft}^{3} / \mathrm{s}$ near Kuiaha Gulch (station L13). Half of the seepage-run measurement reaches had seepage-gain rates between 1.7 and $3.1 \mathrm{ft}^{3} / \mathrm{s} / \mathrm{mi}$, whereas the other half had seepageloss rates of 0.1 to $1 \mathrm{ft}^{3} / \mathrm{s} / \mathrm{mi}$. Four of the seepage-run measurement reaches had seepage flows within 5 percent of the upstream discharges in the reaches.

Ha' $i k \bar{u}$ Ditch. - Two seepage-run measurement reaches were selected for the Ha'ikū Ditch, and both reaches are mainly of tunnel construction. Discharge measurements made on August 11, 2011, ranged from $3.05 \mathrm{ft}^{3} / \mathrm{s}$ near East Kuiaha Gulch (station H4) to 22.2 $\mathrm{ft}^{3} / \mathrm{s}$ near Manawaiiao Stream (station H1) and near Kaupakulua Gulch (station H3). Discharge measurements showed a seepage-loss rate of $0.8 \mathrm{ft}^{3} / \mathrm{s} / \mathrm{mi}$ in the upstream seepage-run measurement reach (stations $\mathrm{H} 1$ to $\mathrm{H} 3$ ) and a seepage gain-rate of $0.2 \mathrm{ft}^{3} / \mathrm{s} / \mathrm{mi}$ at the downstream seepage-run measurement reach (stations H4 to H5). These seepage flows were within 5 percent of the upstream discharges in the measurement reaches. 
Table 4. Seepage-run measurement reaches with associated discharge measurements, estimated seepage losses and gains, length of measurement reach, and estimated seepage rates of the East Maui Irrigation diversion system, east Maui, Hawai'i.

[Station ID, station identifier that is also referenced in table 3; USGS; U.S. Geological Survey; NWIS, National Water Information System; HST, Hawai 'i Standard Time; $\mathrm{ft}^{3} / \mathrm{s}$, cubic feet per second; mi, mile; $\mathrm{ft}^{3} / \mathrm{s} / \mathrm{mi}$, cubic feet per second per mile of ditch; DS, downstream; US, upstream; nr, near; Rd, road; N.A., not applicable; discharge values that are underlined indicate diversion inflow within the seepage-run measurement reach; seepage rates in bold denote rates that departed from the general range of seepage rates observed at other seepage-run measurement reaches]

\begin{tabular}{|c|c|c|c|c|c|c|c|c|c|}
\hline \multirow{2}{*}{$\begin{array}{l}\text { Station } \\
\text { ID }\end{array}$} & \multirow[t]{2}{*}{ Station name in USGS NWIS database } & \multirow[t]{2}{*}{ Date } & \multirow{2}{*}{$\begin{array}{c}\text { Time } \\
\text { (HST) }\end{array}$} & \multirow{2}{*}{$\begin{array}{c}\text { Dis- } \\
\text { charge } \\
\left(\mathrm{ft}^{3} / \mathrm{s}\right)\end{array}$} & \multirow{2}{*}{$\begin{array}{l}\text { Measure- } \\
\text { ment } \\
\text { rating }\end{array}$} & \multicolumn{2}{|c|}{$\begin{array}{c}\text { Seepage loss } \\
\text { or gain }\end{array}$} & \multirow{2}{*}{$\begin{array}{l}\text { Length of } \\
\text { meaurement } \\
\text { section }(\mathrm{mi})\end{array}$} & \multirow{2}{*}{$\begin{array}{c}\text { Seepage } \\
\text { rate } \\
\left(\mathrm{ft}^{3} / \mathrm{s} / \mathrm{mi}\right)\end{array}$} \\
\hline & & & & & & $\left(\mathrm{ft}^{3} / \mathrm{s}\right)$ & (percent) & & \\
\hline \multicolumn{10}{|c|}{ Ko'olau and Wailoa Ditches } \\
\hline $\mathrm{K} 1$ & Koolau Ditch at Makapipi tunnel, Maui, HI & $06 / 13 / 11$ & 1126 & 8.53 & Good & -2.75 & -32.2 & 0.26 & -11 \\
\hline $\mathrm{K} 2$ & Koolau Ditch DS overflow nr Makapipi, Maui, HI & $06 / 13 / 11$ & 1130 & 5.78 & Fair & & & & \\
\hline $\mathrm{K} 3$ & Koolau Ditch .27 mi DS Makapipi tunnel, Maui, HI & $06 / 13 / 11$ & 1152 & 6.17 & Fair & -1.15 & -18.6 & 0.38 & -3.0 \\
\hline K5 & Awaimakaino input nr Koolau Ditch, Maui, HI & $06 / 13 / 11$ & 1230 & $\underline{1.60}$ & Good & & & & \\
\hline K6 & Koolau Ditch nr Hanawi, Maui, HI & 06/13/11 & 1307 & 6.62 & Fair & & & & \\
\hline K1 & Koolau Ditch at Makapipi tunnel, Maui, HI & $06 / 13 / 11$ & 1329 & 6.94 & Good & -0.56 & -8.4 & 0.26 & -2.2 \\
\hline $\mathrm{K} 1$ & Koolau Ditch at Makapipi tunnel, Maui, HI & $06 / 13 / 11$ & 1353 & 6.43 & Good & & & & \\
\hline $\mathrm{K} 2$ & Koolau Ditch DS overflow nr Makapipi, Maui, HI & $06 / 13 / 11$ & 1400 & 6.12 & Good & & & & \\
\hline K10 & Koolau Ditch nr Kopiliula, Maui, HI & 06/13/11 & 1740 & 29.2 & Good & & & & \\
\hline K9 & Koolau Ditch DS Puakaa input, Maui, HI & $06 / 14 / 11$ & 1145 & 25.2 & Good & 0.6 & 2.4 & 0.20 & 3 \\
\hline K10 & Koolau Ditch nr Kopiliula, Maui, HI & $06 / 14 / 11$ & 1118 & 25.8 & Good & & & & \\
\hline K11 & Koolau Ditch nr Kaleomaui Stream, Maui, HI & $06 / 14 / 11$ & 1428 & 44.1 & Fair & -0.6 & -1.4 & 0.41 & -2 \\
\hline K11 & Koolau Ditch nr Kaleomaui Stream, Maui, HI & $06 / 14 / 11$ & 1500 & 44.4 & Fair & & & & \\
\hline K12 & Koolau Ditch near Keanae, Maui, HI & $06 / 14 / 11$ & 1424 & 42.9 & Good & & & & \\
\hline $\mathrm{K} 12$ & Koolau Ditch near Keanae, Maui, HI & $06 / 14 / 11$ & 1501 & 44.3 & Good & & & & \\
\hline $\mathrm{K} 1$ & Koolau Ditch at Makapipi tunnel, Maui, HI & $09 / 12 / 11$ & 1038 & 2.80 & Good & -0.52 & -17.9 & 0.55 & -0.94 \\
\hline $\mathrm{K} 1$ & Koolau Ditch at Makapipi tunnel, Maui, HI & $09 / 12 / 11$ & 1104 & 2.96 & Good & & & & \\
\hline K1 & Koolau Ditch at Makapipi tunnel, Maui, HI & $09 / 12 / 11$ & 1131 & 2.93 & Good & & & & \\
\hline NH1 & New Hamakua Ditch nr Nailiilihaele, Maui, HI & 08/10/11 & 1110 & 0.52 & Good & & & & \\
\hline $\mathrm{NH} 2$ & New Hamakua Ditch at Kailua, Maui, HI & 08/10/11 & 1111 & 0.76 & Fair & & & & \\
\hline NH3 & New Hamakua Ditch at Ohanui, Maui, HI & 08/10/11 & 1313 & 0.83 & Good & 0.24 & 28.9 & 0.80 & 0.30 \\
\hline NH4 & New Hamakua Ditch at Hoalua, Maui, HI & 08/10/11 & 1315 & 1.07 & Good & & & & \\
\hline NH5 & New Hamakua Ditch nr Hanehoi, Maui, HI & 08/10/11 & 1444 & 1.09 & Good & 0.03 & 2.7 & 0.72 & 0.04 \\
\hline NH5 & New Hamakua Ditch nr Hanehoi, Maui, HI & 08/10/11 & 1516 & 1.15 & Good & & & & \\
\hline NH5 & New Hamakua Ditch nr Hanehoi, Maui, HI & 08/10/11 & 1544 & 1.12 & Good & & & & \\
\hline NH6 & New Hamakua Ditch at Waipio, Maui, HI & 08/10/11 & 1503 & 1.15 & Fair & & & & \\
\hline KH1 & Kauhikoa Ditch US of Opana Basin, Maui, HI & $09 / 13 / 11$ & 1031 & 1.35 & Good & 0.32 & 23.9 & 1.61 & 0.20 \\
\hline KH1 & Kauhikoa Ditch US of Opana Basin, Maui, HI & 09/13/11 & 1104 & 1.33 & Good & & & & \\
\hline $\mathrm{KH} 2$ & Calasa intake nr Kauhikoa Ditch, Maui, HI & 09/13/11 & 0921 & $\underline{0.040}$ & p Poor & & & & \\
\hline KH3 & Kauhikoa Ditch US of Silva Intake, Maui, HI & 09/13/11 & 1021 & 1.74 & Good & & & & \\
\hline KH3 & Kauhikoa Ditch US of Silva Intake, Maui, HI & 09/13/11 & 1103 & 1.65 & Good & & & & \\
\hline
\end{tabular}


Table 4. Seepage-run measurement reaches with associated discharge measurements, estimated seepage losses and gains, length of measurement reach, and estimated seepage rates of the East Maui Irrigation diversion system, east Maui, Hawai'i.-Continued

[Station ID, station identifier that is also referenced in table 3; USGS; U.S. Geological Survey; NWIS, National Water Information System; HST, Hawai ${ }^{i}$ i Standard Time; $\mathrm{ft}^{3} / \mathrm{s}$, cubic feet per second; mi, mile; $\mathrm{ft}^{3} / \mathrm{s} / \mathrm{mi}$, cubic feet per second per mile of ditch; DS, downstream; US, upstream; nr, near; Rd, road; N.A., not applicable; discharge values that are underlined indicate diversion inflow within the seepage-run measurement reach; seepage rates in bold denote rates that departed from the general range of seepage rates observed at other seepage-run measurement reaches]

\begin{tabular}{|c|c|c|c|c|c|c|c|c|c|}
\hline \multirow{2}{*}{$\begin{array}{l}\text { Station } \\
\text { ID }\end{array}$} & \multirow[t]{2}{*}{ Station name in USGS NWIS database } & \multirow[t]{2}{*}{ Date } & \multirow{2}{*}{$\begin{array}{c}\text { Time } \\
\text { (HST) }\end{array}$} & \multirow{2}{*}{$\begin{array}{c}\text { Dis- } \\
\text { charge } \\
\left(\mathrm{ft}^{3} / \mathrm{s}\right)\end{array}$} & \multirow{2}{*}{$\begin{array}{c}\text { Measure- } \\
\text { ment } \\
\text { rating }\end{array}$} & \multicolumn{2}{|c|}{$\begin{array}{l}\text { Seepage loss } \\
\text { or gain }\end{array}$} & \multirow{2}{*}{$\begin{array}{c}\text { Length of } \\
\text { meaurement } \\
\text { section (mi) }\end{array}$} & \multirow{2}{*}{$\begin{array}{c}\text { Seepage } \\
\text { rate } \\
\left(\mathrm{ft}^{3} / \mathrm{s} / \mathrm{mi}\right)\end{array}$} \\
\hline & & & & & & $\left(\mathrm{ft}^{3} / \mathrm{s}\right)$ & (percent) & & \\
\hline \multicolumn{10}{|c|}{ Spreckels Ditch at Pāpa'a‘ea } \\
\hline SP1 & Spreckels-Papaaea DS Kaaiea input, Maui, HI & $06 / 16 / 11$ & 1202 & 0.29 & Good & -0.20 & -71.4 & 0.26 & -0.77 \\
\hline SP1 & Spreckels-Papaaea DS Kaaiea input, Maui, HI & $06 / 16 / 11$ & 1221 & 0.28 & Good & & & & \\
\hline SP2 & Spreckels-Papaaea US Makanali input, Maui, HI & $06 / 16 / 11$ & 1219 & 0.080 & Good & & & & \\
\hline SP2 & Spreckels-Papaaea US Makanali input, Maui, HI & $06 / 16 / 11$ & 1237 & 0.090 & Good & & & & \\
\hline SP3 & Spreckels-Papaaea nr Oopuola, Maui, HI & $06 / 16 / 11$ & 1405 & 1.02 & Good & -0.13 & -12.7 & 0.15 & -0.87 \\
\hline SP4 & Spreckels-Papaaea at Papaaea flume, Maui, HI & $06 / 16 / 11$ & 1355 & 0.89 & Good & & & & \\
\hline \multicolumn{10}{|c|}{ Manuel Luis, Center, and Lowrie Ditches } \\
\hline ML1 & Manuel Luis Ditch nr Punalau, Maui, HI & $06 / 15 / 11$ & 1100 & 0.33 & Fair & -0.09 & -27.3 & 0.28 & -0.3 \\
\hline ML2 & Manuel Luis Ditch at Puohokamoa Stream, Maui, HI & $06 / 15 / 11$ & 1102 & 0.24 & Fair & & & & \\
\hline ML3 & Manuel Luis Ditch nr Puohokamoa, Maui, HI & $06 / 15 / 11$ & 1209 & 0.82 & Good & -0.06 & -7.5 & 0.35 & -0.2 \\
\hline ML3 & Manuel Luis Ditch nr Puohokamoa, Maui, HI & $06 / 15 / 11$ & 1241 & 0.79 & Good & & & & \\
\hline ML4 & Manuel Luis Ditch nr Wahinepee Rd, Maui, HI & $06 / 15 / 11$ & 1225 & 0.88 & Good & & & & \\
\hline ML4 & Manuel Luis Ditch nr Wahinepee Rd, Maui, HI & $06 / 15 / 11$ & 1245 & 0.71 & Good & & & & \\
\hline ML4 & Manuel Luis Ditch nr Wahinepee Rd, Maui, HI & $06 / 15 / 11$ & 1308 & 0.78 & Good & & & & \\
\hline ML5 & Manuel Luis Ditch DS Wahinepee input, Maui, HI & $06 / 15 / 11$ & 1442 & 1.15 & Fair & 0.04 & 3.5 & 0.30 & 0.1 \\
\hline ML6 & Manuel Luis Ditch nr Waikamoi, Maui, HI & $06 / 15 / 11$ & 1449 & 1.19 & Fair & & & & \\
\hline $\mathrm{C} 1$ & Center Ditch DS of Kolea input, Maui, HI & $06 / 16 / 11$ & 0939 & 3.35 & Fair & 0.26 & 7.9 & 0.58 & 0.45 \\
\hline $\mathrm{C} 1$ & Center Ditch DS of Kolea input, Maui, HI & $06 / 16 / 11$ & 1011 & 3.24 & Fair & & & & \\
\hline $\mathrm{C} 2$ & Center Ditch US of Punaluu input, Maui, HI & $06 / 16 / 11$ & 1000 & 3.61 & Good & & & & \\
\hline $\mathrm{C} 2$ & Center Ditch US of Punaluu input, Maui, HI & $06 / 16 / 11$ & 1046 & 3.51 & Good & & & & \\
\hline $\mathrm{C} 3$ & Center Ditch DS of Makanali intake, Maui, HI & $06 / 16 / 11$ & 1515 & 4.03 & Good & -0.31 & -7.7 & 0.28 & -1.1 \\
\hline $\mathrm{C} 4$ & Center Ditch US of Oopuola intake, Maui, HI & $06 / 16 / 11$ & 1523 & 3.72 & Fair & & & & \\
\hline L1 & Lowrie Ditch DS Kailua intake, Maui, HI & 08/08/11 & 1040 & 15.6 & Fair & 1.0 & 6.5 & 0.43 & 2.3 \\
\hline L1 & Lowrie Ditch DS Kailua intake, Maui, HI & 08/08/11 & 1125 & 15.2 & Fair & & & & \\
\hline L2 & Lowrie Ditch nr Hoalua, Maui, HI & 08/08/11 & 1052 & 16.9 & Good & & & & \\
\hline L2 & Lowrie Ditch nr Hoalua, Maui, HI & 08/08/11 & 1125 & 16.0 & Good & & & & \\
\hline L3 & Lowrie Ditch DS Hoalua intake, Maui, HI & 08/08/11 & 1238 & 18.7 & Fair & -0.7 & -3.7 & 0.66 & -1 \\
\hline L4 & Lowrie Ditch US Hanehoi intake, Maui, HI & 08/08/11 & 1249 & 18.0 & Good & & & & \\
\hline L5 & Lowrie Ditch DS Hoolawanui intake, Maui, HI & 08/08/11 & 1441 & 18.8 & Fair & 2.1 & 11.2 & 0.67 & 3.1 \\
\hline L6 & Lowrie Ditch US Honopou intake, Maui, HI & 08/08/11 & 1516 & 20.9 & Good & & & & \\
\hline L7 & Lowrie Ditch DS siphon at Honopou, Maui, HI & $08 / 09 / 11$ & 0956 & 30.6 & Good & -0.5 & -1.6 & 1.10 & -0.4 \\
\hline L7 & Lowrie Ditch DS siphon at Honopou, Maui, HI & $08 / 09 / 11$ & 1033 & 31.0 & Good & & & & \\
\hline L8 & Lowrie Ditch US Kapalaalea input, Maui, HI & 08/09/11 & 1008 & 30.3 & Good & & & & \\
\hline L9 & Peahi flume leak nr Lowrie Ditch, Maui, HI & $06 / 17 / 11$ & 0936 & 0.10 & Fair & N.A. & N.A. & N.A. & N.A. \\
\hline L9 & Peahi flume leak nr Lowrie Ditch, Maui, HI & $06 / 17 / 11$ & 0945 & 0.090 & Fair & & & & \\
\hline L9 & Peahi flume leak nr Lowrie Ditch, Maui, HI & $08 / 09 / 11$ & 1228 & 0.24 & Fair & & & & \\
\hline L9 & Peahi flume leak nr Lowrie Ditch, Maui, HI & 08/09/11 & 1240 & 0.24 & Fair & & & & \\
\hline L10 & Lowrie Ditch DS of Peahi flume, Maui, HI & $08 / 09 / 11$ & 1221 & 32.8 & Fair & -0.3 & -0.9 & 2.23 & -0.1 \\
\hline L10 & Lowrie Ditch DS of Peahi flume, Maui, HI & $08 / 09 / 11$ & 1251 & 31.6 & Fair & & & & \\
\hline L11 & Lowrie Ditch nr Kaupakulua, Maui, HI & 08/09/11 & 1223 & 31.9 & Good & & & & \\
\hline L12 & Lowrie Ditch DS Kaupakulua Reservoir, Maui, HI & 08/09/11 & 1436 & 39.7 & Good & 1.6 & 4.0 & 0.95 & 1.7 \\
\hline L13 & Lowrie Ditch US siphon at Kuiaha, Maui, HI & 08/09/11 & 1449 & 41.3 & Fair & & & & \\
\hline
\end{tabular}


Table 4. Seepage-run measurement reaches with associated discharge measurements, estimated seepage losses and gains, length of measurement reach, and estimated seepage rates of the East Maui Irrigation diversion system, east Maui, Hawai'i.-Continued

[Station ID, station identifier that is also referenced in table 3; USGS; U.S. Geological Survey; NWIS, National Water Information System; HST, Hawai 'i Standard Time; $\mathrm{ft}^{3} / \mathrm{s}$, cubic feet per second; mi, mile; $\mathrm{ft}^{3} / \mathrm{s} / \mathrm{mi}$, cubic feet per second per mile of ditch; DS, downstream; US, upstream; nr, near; Rd, road; N.A., not applicable; discharge values that are underlined indicate diversion inflow within the seepage-run measurement reach; seepage rates in bold denote rates that departed from the general range of seepage rates observed at other seepage-run measurement reaches]

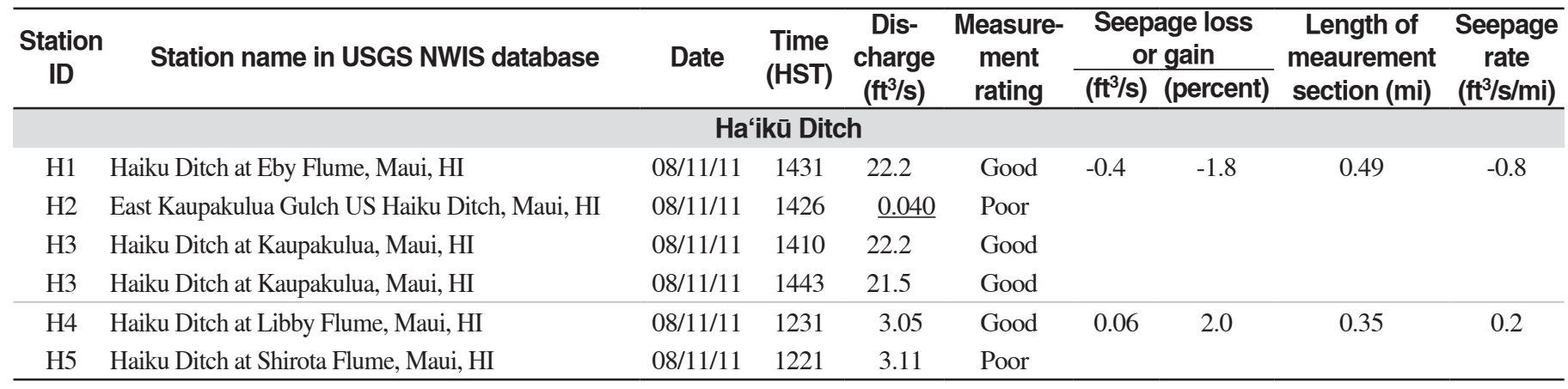

\section{Summary and Conclusions}

In response to CWRM's need for determining efficiency of the EMI diversion system, the USGS conducted a field study from March to October 2011 to assess the amount of seepage losses and gains in the four primary ditches of the diversion system. The four primary ditches of the EMI diversion system are the Wailoa, New Hāmākua, Lowrie, and Ha'ikū Ditches. Additional ditches that connect to the primary ditches include the Ko 'olau, Spreckels, Kauhikoa, Spreckels at Pāpa 'a'ea, Manuel Luis, and Center Ditches. The first part of this study characterized the individual ditch systems from Makapipi Stream to Māliko Gulch as tunnel or open ditch and as lined, partially lined, and unlined for the open ditches. The second part of this study involved making a series of sameday discharge measurements or seepage runs along selected reaches in the diversion system to determine seepage losses and gains. Seepage rates, expressed in cubic feet per second per mile of ditch, were computed. No seepage runs were made in Spreckels Ditch, because the ditch was under repair during the time of the study.

Ditch characteristics for about 63 miles of the EMI diversion system, excluding abandoned ditches and stream conveyances, were identified during field reconnaissance. The longest ditch in the EMI diversion system is Lowrie Ditch (12.4 miles), followed by Ko'olau, Ha 'ikū, and Wailoa Ditches that are each about 10 miles in length. Within the EMI diversion system, about 17 miles of open ditches were surveyed, in which 11 miles are unlined, 3.5 miles are lined, and 2.5 miles are partially lined. The Wailoa, Kauhikoa, and Ha 'ikū Ditches have greater than 96 percent of their lengths as tunnels, with very few lined open-ditch sections and those are mostly concrete flumes. More than half of Lowrie Ditch and Spreckels Ditch at Pāpa 'a'ea are open-ditches and a majority of those are unlined. Partially lined open-ditch sections are scarce, and they are most common in the Spreckels and New Hāmākua Ditches. Because
EMI regularly maintains and repairs its diversion system, the ditch characteristics documented in this report are only representative of the 2011 study period.

Discharge measurements were made along 26 seepage-run measurement reaches during relatively stable flow conditions in June, August, and September of 2011. Results indicate that Ko olau Ditch and Spreckels Ditch at Pāpa'a'ea generally had seepage losses within the measurement reaches. Wailoa and Kauhikoa Ditches each had only one seepage-run measurement reach and both of them had seepage gains. Manuel Luis, Center, Lowrie, and Ha 'ikū Ditches had variable seepage losses and gains in the seepage-run measurement reaches. Seepage-loss rates in the EMI diversion system generally ranged from 0.1 to $3.0 \mathrm{ft}^{3} / \mathrm{s} / \mathrm{mi}$, and seepage-gain rates ranged from 0.04 to $5.2 \mathrm{ft}^{3} / \mathrm{s} / \mathrm{mi}$, with the exception of two measurement reaches along Ko'olau Ditch that had seepage flows outside of the general range of seepage losses and gains. Discharge measurements in the open-ditch seepage-run measurement reaches-lined and unlined-generally indicated seepage losses, whereas measurements in the tunnel reaches generally indicated seepage gains. No partially lined open-ditch measurement reaches were selected, because they were limited to very short reaches at diversion intakes and repaired sections of the ditch. Three seepage-run measurement reaches do not have a dominant ditch characteristic, and they consisted of fairly similar distributions of tunnel and unlined open-ditch sections. These three seepage-run measurement reaches had seepage gains.

The seepage loss or gain for each of the seepagerun measurement reaches was computed as the difference between the downstream and upstream flows, excluding any estimated or measured diversion inflows and outflows within the seepage-run measurement reach. The seepage rates were only applicable to the measurement reaches where discharges were measured. Typically, seepage flows cannot be visually 
detected, especially in tunnels, and multiple seepage losses and gains may be occurring simultaneously at different locations along a ditch. Some of the factors that affect ditch seepage flow include ditch size and construction, frequency of maintenance and repair, wetted perimeter, and head. In some cases, the estimated seepage losses and gains fall within the standard of error associated with the accuracy of the discharge measurements. For these cases, estimated seepage rates may represent the true seepage loss or gain within the measurement reaches. However, it is also possible that these seepage rates may reflect uncertainty in the discharge measurements. Uncertainty in measured seepage losses and gains for individual ditches in the EMI diversion system can be reduced with additional measurements. Also, discharge measurements are needed to characterize seepage losses and gains for parts of the EMI diversion system that were not considered in this study, including the Spreckels Ditch that was being repaired at the time of this study.

\section{References Cited}

Giambelluca, T.W., Chen, Q., Frazier, A.G., Price, J.P., Chen, Y.-L., Chu, P.-S., Eischeid, J., and Delparte, D., 2011, The rainfall atlas of Hawai 'i: University of Hawai 'i at Mānoa Web site, accessed December 22, 2011 at http://rainfall. geography.hawaii.edu.

Gingerich, S.B., 1999, Ground-water occurrence and contribution to streamflow, northeast Maui, Hawai'i: U.S. Geological Survey Water-Resources Investigations Report 99-4090, 69 p.
Hawaiian Commercial and Sugar Company, 2010, Appendix B-Water lost from the EMI System; Submission to State of Hawai' $i$ Department of Land and Natural Resources, Commission on Water Resource Management March 19, 2010: accessed October 28, 2011, at http://hawaii.gov/dlnr/ cwrm/activity/iifsmaui1/PR201001.pdf.

Kumu Pono Associates, LLC, 2001, Wai o ke ola: He wahi mo'olelo no Maui Hikina-A collection of native traditions and historical accounts of the lands of Hāmākua Poko, Hāmākua Loa and Ko‘olau, Maui Hikina (East Maui), Island of Maui: Hilo, Hawai ‘i, Kumu Pono Associates, LLC, report prepared for East Maui Irrigation Company, 544 p.

Rantz, S.E., and others, 1982, Measurements and computation of streamflow, volumes 1 and 2: U.S. Geological Survey Water-Supply Paper 2175, 631 p.

Schroeder, T.A., 1993, Climate controls, in M. Sanderson, ed., Prevailing trade winds, weather and climate in Hawai 'i: Honolulu, Hawai ‘i, University of Hawai 'i Press, 12-36 p.

State of Hawai 'i Department of Land and Natural Resources, 2010, Staff submittal for the meeting of the Commission on Water Resource Management on May 25, 2010, Pā'ia, Maui: State of Hawai 'i Department of Land and Natural Resources online archive accessed October 12, 2011, at http://www. state.hi.us/dlnr/cwrm/newsevents_commissionmtg.htm.

Turnipseed, D.P., and Sauer, V.B., 2010, Discharge measurements at gaging stations: U.S. Geological Survey Techniques and Methods book 3, chap A8, 87 p. (Also available at http://pubs.usgs.gov/tm/tm3-a8/.)

Wilcox, C., 1996, Sugar water; Hawaii's plantation ditches: Honolulu, University of Hawai ‘i Press, 191 p. 


\section{Appendix-Ditch characteristics and seepage rates of the East Maui Irrigation diversion system, east Maui, Hawai'i}




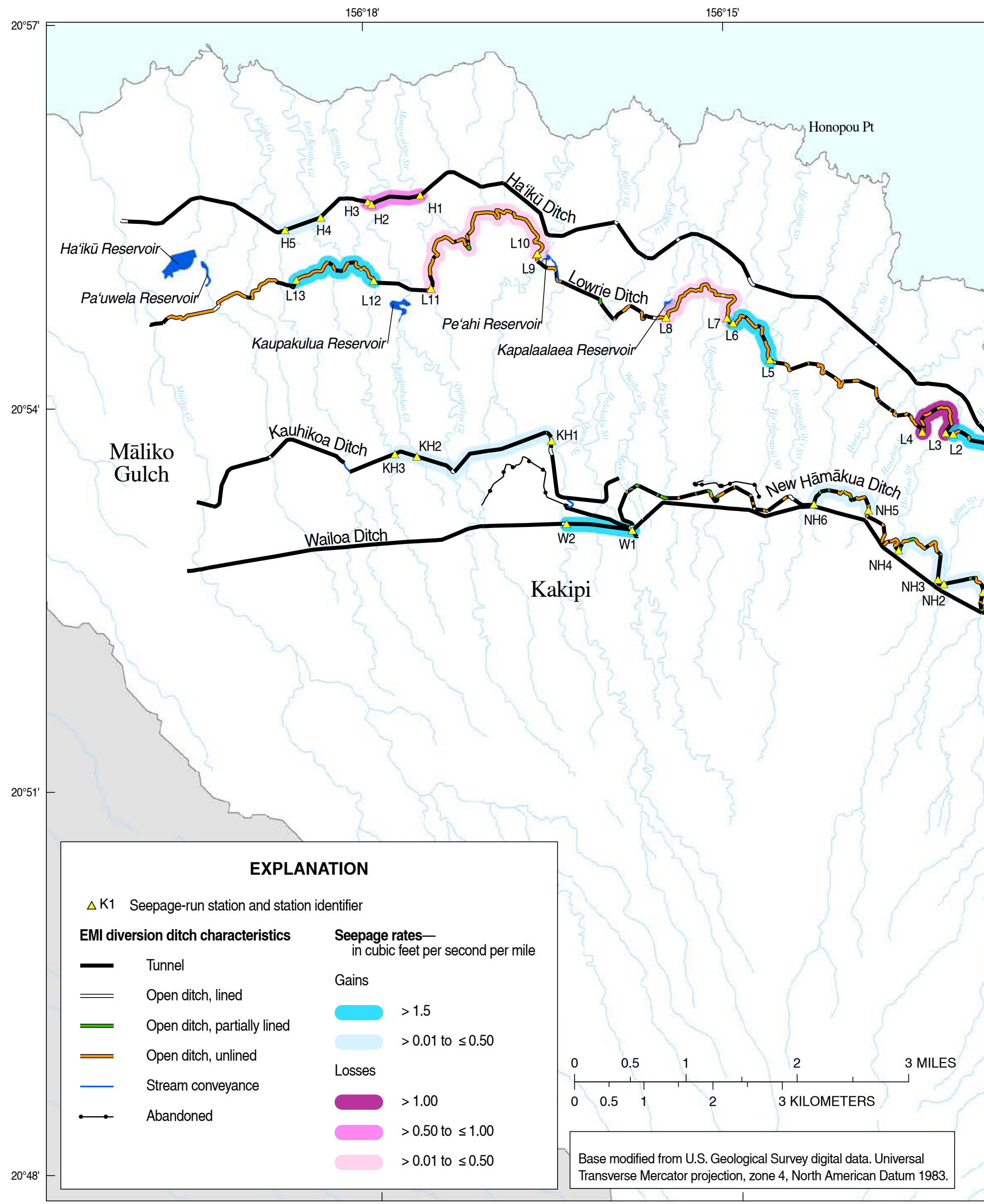

Appendix. Ditch characteristics and seepage rates of the East Maui Irrigation (EMI) diversion system, east Maui, Hawai'i. 
This page left intentionally blank. 
Produced in the Western Region, Menlo Park, California Manuscript approved for publication, May 25, 2012

Edited by James Hendley II

Layout by Jeanne S. DiLeo 


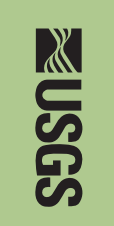

$\stackrel{\rho}{\frac{0}{\sigma}}$

$\stackrel{\mathbb{1}}{\overparen{D}}$

$\frac{1}{3}$

禺

弯

음

曲

总

요

ڤั)

วั้

क्ष.

I

Q

골.

$\bar{B}$

흉

뭉

음

禹

ग

일

5

공

I

밈

市

ग刃

$\frac{N}{N}$ 